\title{
AIR POLLUTION AND INFANT MORTALITY: EVIDENCE FROM THE EXPANSION OF NATURAL GAS INFRASTRUCTURE*
}

\author{
Resul Cesur, Erdal Tekin, and Aydogan Ulker
}

We examine the impact of widespread adoption of natural gas as a source of fuel on infant mortality in Turkey, using variation across provinces and over time in the intensity of natural gas utilisation. Our estimates indicate that the expansion of natural gas infrastructure has resulted in a significant decrease in the rate of infant mortality. Specifically, a one-percentage point increase in natural gas intensity - measured by the rate of subscriptions to natural gas services - would cause the infant mortality rate to decrease by 4\%, which would translate into approximately 348 infant lives saved in 2011 alone.

*Corresponding author: Erdal Tekin, Department of Public Administration and Policy, School of Public Affairs, American University, IZA, and NBER, 4400 Massachusetts Ave, NW, Washington DC, 20016-8070. Email: tekin@american.edu.

We would like to thank two anonymous referees, Laura Arygs, Şaduman Cesur, Ala Cubukcu, Francesc Ortega, Stephen Ross, and the participants at the 2013 Health Economics Spring Meeting of the National Bureau of Economic Research, George Mason University, Queens College of the City University of New York, University of Connecticut, Johns Hopkins University, IZA Workshop on Labor Market Effects of Environmental Policies, the 2012 Southern Economic Association Meeting, and the 2013 European Society for Population Economics Conference for their comments and suggestions. Chandler McClellan provided excellent research assistance. 
Concerns over the consequences of global climate change on public health and communities around the world have raised widespread awareness of an urgent need for developing technologies and practices that would enable a carbon-free future as well as sustainable development (Acemoglu et al., 2012). There is little dispute that burning of coal, which produces far more carbon than any other fuel, is a major contributor to global climate change and worsening air quality in many parts of the world. Despite this agreement, consumption of coal continues to rise at a pace that now presents a formidable threat to some of the gains in health outcomes achieved by the developing world over the last several decades. Furthermore, efforts aimed at reducing carbon emissions through environmental regulations have produced little success. This is in part due to the reluctance of emerging economies to committing to legal obligations as they face mounting pressure to sustain their economic development. ${ }^{1}$ Accordingly, it seems that any viable solution to the problem of global climate change ought to involve actions that are not only voluntary, but also in the economic interest of these countries. One such example is the investments undertaken by countries to diversify their energy portfolios, and thereby to reduce the vulnerability of their economies to global supply shortages in any particular fuel. To the extent that these actions would result in less-carbon intensive energy portfolios, they could reduce air pollution and produce benefits for the environment and public health.

In this paper, we consider the health effects of one such action adopted by the Republic of Turkey, which has begun investing in building a natural gas infrastructure in 1980s by expanding a network of pipelines originating in its neighbours, including Russia

\footnotetext{
${ }^{1}$ There are also challenges to effective enforcement of regulations due to weak governance and corruption in many parts of the world (Jayachandran, 2009; Greenstone and Hanna, in press).
} 
and Iran. This infrastructure, which has enabled 61 of the 81 Turkish provinces to gain access to natural gas to this date, has led to a widespread replacement of the consumption of coal by natural gas for residential and commercial space heating and cooking purposes (see Figure 1 for the number of provinces with access to natural gas over time). As we discuss below, this has led to significant improvements in air quality in these provinces. This is not surprising because combustion of natural gas emits virtually no sulphur oxide, which is a key component of acid rain. Furthermore, emissions of total particulate matter, carbon monoxide, and nitrogen oxide are also at much lower levels from burning of natural gas compared to coal. Then an important question to consider is whether the expansion of the natural gas infrastructure has had any impact on infant mortality. To the best of our knowledge, the current study is the first attempt in the literature to examine the effect of a nationwide change in a fuel delivery system on infant health. The knowledge to be gained from this analysis has far-reaching implications as similar investment processes have been taking place in other parts of the world, including Latin America, Europe, and $\mathrm{Asia}^{2}$. As the consumption of natural gas continues to rise, any impact is likely to be felt beyond the borders of investing countries through global air circulation patterns.

The current investigation is particularly timely because of the recent spike in the supply of natural gas, enabled by an extraction technology called hydraulic fracturing or "fracking." The impact of fracking boom on energy markets has been especially spectacular in the United States, which has seen its natural gas production to rise by $25 \%$

\footnotetext{
${ }^{2}$ A few examples include the recently opened North Stream pipeline from Russia to Germany through the Baltic Sea, the Mazatlan pipeline project in Mexico, and Myanmar-China and Kazakhstan-China pipeline projects.

${ }^{3}$ Fracking involves the process of injecting sand, water, and certain chemicals into shale rocks to crack them open and release the natural gas trapped inside.
} 
since 2010 and recently outstripped Russia as the world's largest gas producer (Morse, 2014). The proponents argue that fracking is not only an economically sound practice, but also an environmentally friendly one as it replaces coal-fired power plants with those using natural gas. Accordingly, they claim that natural gas could serve as a "bridge fuel" towards the eventual replacement of carbon-based fossil fuels by renewable energy sources (Podesta and Wirth, 2009; Paltsev et al., 2011). However, there is also a deep scepticism among many experts and policymakers about the so-called benefits of fracking for the environment and public health. The sceptics worry about the potential environmental damages that might be caused by gas extraction through fracking, such as the release of methane gas to the atmosphere, underground water contamination, discharge of toxic chemicals during the process, and physical impacts in the form of increased seismic activity, and argue that the net benefits may be negligible or even negative as a result (Finkel, 2011; Caulton et al., 2014; Krupp, 2014). ${ }^{4}$

This paper also extends the growing literature on air pollution and infant mortality in developing countries by using a novel source of variation from a country that has not been studied in this context. Despite growing concerns about the harmful health impacts of air pollution in developing countries, most of the available evidence on the subject comes from the United States and a few other developed countries (e.g., Chay and Greenstone, 2003a,b; Currie and Neidell, 2005; Currie et al., 2009, 2011; Currie and Walker, 2011; Knittel et al., 2011). ${ }^{5}$ One explanation for the relative paucity of evidence

\footnotetext{
${ }^{4}$ There is currently little evidence available on the health impacts of fracking (Mitka, 2012; Mash et al., 2014). While investigating the health impacts of this practice is an extremely important question, it is beyond the main focus of our paper.

${ }^{5}$ There are several explanations offered for the pathways through which prenatal exposure to air pollution can affect infant health. For example, it has been suggested that exposure to pollutants like carbon monoxide and particulate matter could lead to impaired foetal tissue growth through oxygen deprivation
} 
from developing countries is the fact that policy changes and environmental regulations in the developing world are rare and weakly enforced, failing to generate enough variation in air pollution levels to detect statistically significant effects (Arceo-Gomez et al., 2012; Tanaka, 2012). In the absence of exogenous sources of variation, the associations obtained in much of the earlier research on air pollution and health may reflect the impact of omitted factors, such as socio-economic status, that are correlated with both pollution exposure and health outcomes rather than the impact of air pollution per se. Only recently have researchers responded to this challenge by turning their attention to identifying exogenous sources of variation, which could yield estimates of the causal impact of air pollution on health in developing country settings. ${ }^{6}$

In order to account for unobserved heterogeneity, we rely on the fact that the adoption and the subsequent expansion of the use of natural gas across Turkish provinces have been gradual. In particular, we exploit the variation in both the timing of the adoption of natural gas across provinces and the intensity of natural gas consumption as measured by the number of subscribers to natural gas services per 100 persons. As shown in Figures 1 and 2, both the number of provinces with a natural gas infrastructure and the intensity of its consumption have grown rapidly in Turkey between 2001 and 2011.

Our results indicate that a one-percentage point increase in the rate of subscriptions to natural gas services would result in a $4 \%$ decline in infant mortality rate,

(Dejmek et al., 2000; Ha et al., 2001; Li et al., 2003; Maisonet et al., 2004; Siddiqui et al., 2008). These impacts can be particularly damaging for infants, whose lungs are not developed and immune systems are weak. It is also argued that air pollution can harm the infant through adversely affecting the health of the pregnant mother, for example, by weakening her immune system (Currie et al., 2009).

${ }^{6}$ For example, Jayachandran (2009) studies the impact of particulate matter on infant health using variation in pollutants caused by massive wildfires in Indonesia. Tanaka (2012) uses variation in the regulations on emissions from power plants to examine the impact of air pollution on infant mortality in China. ArceoGomes et al. (2012) exploit the number of thermal inversions as an instrument to investigate the impact of air pollution on infant mortality in Mexico City. Finally, Greenstone and Hanna (in press) study the impact of air and water pollution regulations on infant mortality in India. 
which could translate into approximately 348 infant lives saved in 2011 alone. Our auxiliary analysis using supplemental data on total particulate matter suggests that the reductions in infant mortality associated with the expansion of natural gas services are driven by the improvement in air quality.

\section{Expansion of Natural Gas Infrastructure in Turkey}

Over the last two decades, the Turkish economy has gone through a major transformation marked by rapid growth and structural changes, such as privatisation of state enterprises and integration into global economy. ${ }^{7}$ During the same period, Turkey has also intensified its efforts to diversify its energy portfolio by investing in building a network of natural gas pipelines. The country's close proximity to some of the world's major natural gas producers such as Russia, Iran, and Azerbaijan, has especially played an important role in its decision to raise the share of natural gas in its energy mix. ${ }^{8}$ These efforts have led to an expansion of natural gas networks across Turkish provinces, resulting in a gradual migration from coal to natural gas for space heating and cooking purposes by dwellings and businesses. First introduced in Ankara in 1988 and followed by Istanbul and Bursa in 1992, the natural gas infrastructure has spread rapidly across Turkish provinces since then, especially over the period of 2001-2011 (see Figure 1).

\footnotetext{
${ }^{7}$ Turkey's recognition as a candidate for European Union membership in December 1999 and the accession talks that started in 2005 have brought the country's environmental record under increased scrutiny. This has led to the Turkish government putting in place a number of legislations and regulations to improve energy efficiency and address environmental concerns, including flue gas desulphurisation requirements on all newly commissioned coal-fired power plants, new by-laws on air pollution control from heating in 2005, 2007, and 2009, the ratification of the Kyoto protocol, and setting a unilateral target for carbon emissions introduced by the 2009 National Climate Change Strategy (International Energy Agency, 2009). Furthermore, the use of leaded gasoline was banned in 2004.

${ }^{8}$ Natural gas is imported from mainly Russia and a few other neighbouring countries through pipelines that are operated by the state owned company, BOTAS. It is then transmitted to individual provinces by private distribution companies.
} 
Consequently, this expansion has led to a significant increase in the overall consumption of natural gas. According to the statistics from the International Energy Agency, the total consumption of coal and peat in Turkey increased from 11 Million tons of oil equivalent (Mtoe) to 14 Mtoe between 2000 and 2010, while the total consumption of natural gas almost tripled from 4.9 Mtoe to 13.1 Mtoe during the same period (International Energy Agency, 2012). Similarly, the share of natural gas in electricity production increased from $37 \%$ in 2000 to about $46 \%$ in 2010 . Concurrently, the share of coal decreased mildly from $31 \%$ to $26 \%$. In terms of residential use, the demand for natural gas exhibited an average increase of $28 \%$ between 1990 and 2009, while the demand for coal increased only by 3.6\% (International Energy Agency, 2011). Moreover, the average annual increase in the industrial use of natural gas has been $10.6 \%$ compared to only $1.5 \%$ for coal during that period.

There are a number of factors that are associated with the timing of the adoption and the rate of expansion of natural gas across provinces in Turkey. As we discuss below, these factors are primarily related to economic viability and are unrelated to a particular plan designed to improve health outcomes, especially once observed characteristics of and permanent differences across provinces are accounted for. This is reassuring for our identification strategy, which is explained in detail in Section 3. It is important to keep in mind that the investments in infrastructure required to expand natural gas networks to individual provinces are very costly and often take many years to recoup. Since the establishment and administration of infrastructure at the province level are controlled by privately owned firms, the factors associated with economic viability, such as the number of housing units (or the population size), the climate, the conditions of the geographical 
terrain, and the proximity to main natural gas ports operated by the central government appear to play an important role in the timing of adoption and the rate of expansion (Aras and Aras, 2005). Therefore, it is not surprising that centrally located provinces with large populations and relatively cold and long winters, like Istanbul, Ankara, Bursa, and Eskisehir, are among the early adopters. It is also not surprising that many of the remaining provinces without a natural gas infrastructure are located in the far eastern and southern regions of Turkey since these are areas that are both mountainous and distant from the main ports. Once a province gains access to natural gas, a household's decision to migrate to natural gas for the purposes of heating and cooking is determined by the type of housing unit occupied by the household. For single household residential units, the decision is voluntary. For residential buildings with multiple housing units - the vast majority of living arrangements in Turkey - a majority decision among the residents is required in order to change the system to either individual or central heating with natural gas. $^{9}$

\section{Data and Descriptive Statistics}

\subsection{Data on Natural Gas Intensity in Turkey}

Data on natural gas availability come from the Dogal Gaz Dergisi (Turkish Natural Gas Journal). ${ }^{10}$ The number of provinces with natural gas increased from 5 to 61 between

\footnotetext{
${ }^{9}$ Since our unit of analysis is at the province level, we are unable to distinguish the private and public health benefits associated with natural gas use. However, the analysis at the province level guards us against the potential endogeneity of a household's decision to switch to natural gas. Therefore, our estimates provide the combined effect of natural gas on those who benefit from improved air quality both privately and publicly.

${ }^{10}$ See http://www.dogalgaz.com.tr/ (last accessed: 9 March 2015).
} 
2001 and 2011 (see Figure 1). ${ }^{11}$ However, as shown in Figure 2, the rate of utilisation or the intensity of natural gas use has been gradual and is currently far from complete. Note that there is considerable variation in the rate by which natural gas has expanded across provinces. To illustrate, we present the rate of intensity of natural gas expansion for six select provinces, including Istanbul, Izmir, Bursa, Gaziantep, Kocaeli, and Erzurum in Figure 3. Note that the first four of these provinces are in the top ten with respect to their populations, while the last two are medium sized provinces. As shown in the figure, there is considerable variation across provinces both in terms of the timing of adoption and the growth in the intensity of natural gas.

\subsection{Time-variant Province Characteristics}

We control for a vector of time-variant determinants of infant mortality in our empirical models. These variables are measured at the province-year level and include the number of hospitals and hospital beds per 100,000 persons, the percentage of population with a high school degree, the percentage with a college degree, the number of students per teacher in secondary schools, the number of motor vehicles per 1,000 persons, the unemployment rate, the number of physicians per 100,000 persons, an indicator variable for whether the province has a Family Physician Program, and an indicator variable for whether the political party affiliation of the elected mayor of the central district of the associated province is the same as the political party governing Turkey. ${ }^{12} \mathrm{We}$ also control for income per capita, which is only available at the sub-regional level. ${ }^{13}$ Data on

\footnotetext{
${ }^{11}$ Table A1 presents the list of provinces with natural gas infrastructure by 2011 along with the year of adoption and natural gas intensity in that year.

${ }^{12}$ We construct dummy variables that equal unity for observations with missing data on the explanatory variables.

${ }^{13}$ According to the Turkish Statistical Institute, Turkey is classified into 12 regions, 26 sub-regions, and 81 provinces. These regions and sub-regions are made up of clusters of provinces that are grouped together
} 
province populations are obtained from the Turkish Statistical Institute (TurkStat) for years 2000 and 2007-2011 and from the Turkish Ministry of Health between 2001 and 2006. ${ }^{14}$ Information on the Family Physician Program comes from the Ministry of Health. The remaining control variables are obtained from the TurkStat.

Table 1 shows the means and standard deviations for these characteristics for the full sample as well as various sub-samples. The table reveals that the provinces with and without natural gas differ from each other in a number of characteristics. For example, provinces with natural gas are more likely to have a central district mayor who is affiliated with the ruling party. This is not surprising in a country where the central government maintains major control over resource allocation for local investment projects. Provinces with access to natural gas also have higher number of motor vehicles, per capita income, hospital beds and physicians, individuals with college education, and a higher likelihood of having a family physician program initiated in the province by the government. Again these differences suggest that natural gas penetration is more likely in provinces that are wealthier, more urban, and with more educated populations. On the other hand, there is no difference in unemployment rates between the two types of provinces.

based on geographical convenience and for statistical purposes. The Turkish Statistical Institute is the official governmental agency, which gathers and processes data from a variety of different sources on numerous topics ranging from agriculture to health. See http:/www.turkstat.gov.tr for more information (last accessed: 9 March 2015).

${ }^{14}$ Since no Census was conducted between years 2001 and 2006, the province populations for the period 2001-2006 are based on extrapolations implemented by the Ministry of Health. Alternatively, we imputed the population figures between 2001 and 2006 using province-specific growth rates. Using these values produce results almost identical to those presented in this paper. These results are available from the authors upon request. 


\subsection{Infant Mortality Rate in Turkey}

We obtained annual province-level infant mortality data from the TurkStat and Turkish

Census Bureau for the periods of 2001-2008 and 2009-2011, respectively. ${ }^{15}$ Our analysis sample consists of 877 province-year observations between 2001 and $2011 .{ }^{16}$ As shown in Table 1 , the average infant mortality rate across all provinces and over the period between 2001 and 2011 is 9.18 . However, the average infant mortality rate is higher among province-year observations with natural gas than those without natural gas. Similarly, there is a sharp difference in the rate of infant mortality between provinces, which gained access to natural gas and those, which never did during our analysis period.

\subsection{Under-reporting in Infant Mortality Rate}

It is widely recognised that official statistics on deaths, especially for infants, are incomplete in most developing countries due to under-reporting (e.g., Anderson and Silver, 1986; Becker et al., 1998; Victora and Barros, 2001; Anthopolos and Becker, 2010; Greenstone and Hanna, 2011; Gruber et al., 2014). ${ }^{17}$ Accordingly, there are usually vast differences in the infant mortality rates reported by the national statistical offices of individual countries and those released by international agencies such as the World

\footnotetext{
${ }^{15}$ The province level mortality statistics between 2009 and 2011 were not available from the TurkStat at the time this research was conducted. However, we were able to obtain data for these three years from the Turkish Census Bureau. The data from the two sources are highly consistent. Moreover, year fixed effects would largely account for differences in the data collection procedures between the two agencies to the extent that such differences exist.

${ }^{16}$ Fourteen province-year observations with missing information on infant mortality are dropped from the analysis.

${ }^{17}$ For example, Gruber et al. (2014) study the effects of a healthcare reform implemented in Thailand on health care utilisation and infant mortality. The infant mortality rates that they obtain from the Thailand Ministry of Public Health exhibit large differences from those reported in the World Bank Development Indicator Database. As they report in Table $\mathrm{C} 1$, the vital statistics registry estimates are lower than those of the World Bank by a factor of about 2.5. In a recent paper examining the impact of environmental regulations on infant mortality in India, Greenstone and Hanna (in press) report that the city-level infant mortality data that they employ from Vital Statistics are about a third of the rate documented from state level surveys. In the absence of data on infant mortality from Indonesia, Jayachandran (2009) imputes deaths from "missing children" in the 2000 Census.
} 
Health Organisation (WHO) and the United Nations. The statistics compiled by these agencies usually adjust for under-reporting by combining information from various demographic surveys, census data, and the official vital statistics registries, and make certain modelling assumptions in order to reduce the impact of under-reporting (Lopez et al., 2001; Gruber et al., 2014). The under-reporting in the official statistics is caused by several factors. For example, many deaths, especially those that occur outside of a hospital, go unrecorded (Tangcharoensathien et al., 2006; Anthopolos and Becker, 2010; Gruber et al., 2014). Under-reporting is particularly common for home deliveries and in cases where the new-born dies only a very short period after birth. In fact, it is not uncommon for midwives to announce deaths as stillbirth rather than a live birth shortly after death out of respect to a grieving family (Anthopolos and Becker, 2010). In countries like Turkey, the dead are usually buried shortly (typically before sundown or within hours) after death in accordance with the Islamic tradition, which may also exacerbate the under-registering of infant deaths. Note that the under-reporting is mostly one-sided, i.e., there are far more unreported infant deaths than unreported live births that survive the first year in life (Anthopolos and Becker, 2010).

To illustrate the differences in data on infant mortality in Turkey across various sources, we present the average annual mortality rates obtained from three different agencies in Table A2. The first two columns report the average mortality rates based on estimates from the WHO and the United Nations. The third column shows the infant mortality rate obtained from the TurkStat. It is important to note that province level data on infant mortality do not exist from the WHO and the United Nations. The estimates from the WHO and United Nations rely on data from the TurkStat, summary of birth 
histories conducted in the Turkish Censuses, and information from various waves of the Turkish Demographic and Health Surveys (TDHS) ${ }^{18}$ Therefore, any difference between these three estimates arises from a combination of the way each organisation incorporates information from these sources as well as their own adjustments for under-reporting. While the national averages of infant mortality rate from the TurkStat are lower than those from the two other sources in each year, the trends in the TurkStat and the other two series are similar and the pairwise correlations are very high. In fact, the pairwise correlations between TurkStat and the series from the WHO and the United Nations are both 0.97 . Furthermore, the measurement error (or under-reporting) in the infant mortality rate data obtained from TurkStat is not a problem for our analysis as long as these data are not correlated with the time of adoption and the rate of penetration of natural gas by Turkish provinces. Even under a scenario where such correlations are plausible, the province-specific linear and quadratic trends in addition to province fixed effects included in our models would likely capture those correlations.

To illustrate the issue of measurement error more formally, suppose that the true infant mortality rate is $\mathrm{IMR}_{\mathrm{pt}}{ }^{*}$. Then the observed infant mortality rate can be expressed as

$$
\operatorname{IMR}_{\mathrm{pt}}=\left(1-\mathrm{k}_{\mathrm{pt}}\right) \mathrm{IMR}_{\mathrm{pt}} *
$$

where $\mathrm{IMR}_{\mathrm{pt}}{ }^{*}=$ Actual_Deaths $\mathrm{pt} /$ Live_births $\mathrm{pt}_{\mathrm{pt}} ; \mathrm{IMR}_{\mathrm{pt}}=$ Reported_Deaths $\mathrm{p}_{\mathrm{p}} /$ Live_births $_{\mathrm{pt}}$; and $\mathrm{k}_{\mathrm{pt}}=$ Unreported_Deaths $\mathrm{pt} /$ Actual_Deaths $\mathrm{pt}$. As long as $\mathrm{k}_{\mathrm{pt}}$ is uncorrelated with the

\footnotetext{
${ }^{18}$ Among these Turkish data sources, the TurkStat vital statistics are the only source which provides annual infant mortality rate at the province level. The TDHS are conducted once every 5 years by the Institute of Population Studies at the Hacettepe University in collaboration with the Turkish Ministry of Health. These surveys are only representative at the national level, by urban and rural residence. Although the surveys allow analyses for some of the survey topics for the 12 geographical regions of Turkey, they are unavailable at the province level. Similarly, the Turkish Censuses are not available on an annual basis, and it is not possible to derive province level representative infant mortality rates from them either.
} 
natural gas intensity, the estimate of the impact of natural gas utilisation on infant mortality would be unbiased. It is difficult to conceive of a plausible scenario wherein such a correlation should exist. One argument could be that there might be a positive correlation between the adoption of natural gas and the overall quality in the government services in health care. A failure to account for such heterogeneity would then cause the estimate of the impact of natural gas intensity on infant mortality to be biased upward. However, if the improved quality of care in hospitals results in an increased proportion of births delivered in hospitals rather than homes, then the extent of under-reporting in the infant mortality should go down. In essence, under-reporting should be almost zero if all births are delivered at hospitals. In that case, our estimate would be biased downward. Note that, in our regressions, we control for the number of hospitals, hospital beds, and physicians per capita at the province level as well as an indicator for whether the province has adopted the Family Physician Program. These variables should capture the quality of health care delivery services to a large extent. Also the provinces that adopt natural gas are typically more urban and have a higher average income than others. Therefore, it is plausible to assume that in these provinces, a smaller proportion of births are delivered at homes as opposed to hospitals relative to the provinces with low-incomes and greater share of populations living in rural areas. Furthermore, under-reporting tends to be larger in poor and less urban provinces (Anthopolos and Becker, 2010), but these are also the provinces that are less likely to have access to a natural gas infrastructure. ${ }^{19}$ It can also be argued that the improvements in the quality of health care services may

\footnotetext{
19 In fact, the TurkStat vital statistics miss infant deaths from small villages and remote areas due to reporting errors in death registries. The TurkStat birth statistics, however, cover the entire provinces including small village and remote area births. Hence, it is not surprising that the infant mortality rates from the TurkStat appear to be lower than those from other sources.
} 
account for part of the reduction in infant mortality rate. Note that we further guard against any bias from such omitted factors that may be correlated with both infant mortality and the adoption and expansion of natural gas services across provinces by controlling for province fixed effects and province-specific linear and quadratic time trends in our models. In addition, we include region-by-year fixed effects in our most comprehensive specification. As discussed below, our estimate of the impact of natural gas intensity on infant mortality rate remains remarkably robust to controlling for province-specific trends and region-by-year fixed effects. Similarly, it can also be argued that natural gas penetration might have led to increased awareness in the public, especially among pregnant women, of the harmful effects of air pollution. Then this might have induced them to engage in avoidance behaviour, which might have then reduced their exposure to air pollution. Although any reduction in infant mortality in this case can still be attributed to the treatment, the mechanisms would be different under this scenario. In any case, province-specific linear and quadratic trends along with region-byyear fixed effects would likely control for these unobservable factors.

\section{Identification}

It is useful to highlight the differences between provinces with and without a natural gas infrastructure before we discuss our identification strategy further. To illustrate these differences, we report results from several regressions in Tables 2 and 3. Specifically, each cell in column (1) of Table 2 corresponds to an estimate from a separate regression, where each of the time-varying province characteristic is regressed on a binary indicator for whether a province has natural gas along with year fixed effects. Not surprisingly, the 
estimates in column (1) support the argument made above, i.e., those provinces with and without natural gas exhibit differences on a wide range of characteristics. However, accounting for permanent differences across provinces through province fixed effects in column (2) mitigates many of these differences both statistically and in magnitude. When we further add province-specific linear and quadratic trends and region-by-year fixed effects in the subsequent three columns, we observe that none of the characteristics considered in this analysis is associated with natural gas adoption at the province level. We obtain a very similar pattern when we repeat the same analysis using the natural gas intensity in Table 3.

To gain further insights about the differences in observable characteristics between provinces with and without a natural gas infrastructure, we next run regressions of the binary indicator of natural gas infrastructure and the rate of natural gas subscribers on jointly specified time-varying province characteristics. These results are shown in Tables 4 and 5. Again, many of the control variables are significantly associated with the presence of a natural gas infrastructure or the natural gas intensity in column (1), lending support to the notion that distribution of natural gas networks across provinces is nonrandom and thus could reflect some of the observed and unobserved factors that might also be correlated with infant mortality. However, all of these differences become statistically insignificant and much smaller in magnitude once we account for province fixed effects along with province-specific linear and quadratic trends and region-by-year fixed effects through columns (2) and (5). This is also evidenced from the F-statistics and the corresponding p-values reported at the bottom of the table, which underscore the overall insignificance of all these characteristics once fixed effects and trends are 
accounted for. We interpret these findings as strong evidence demonstrating that any remaining variation in the binary natural gas indicator or natural gas intensity in column (5) is plausibly exogenous to infant mortality.

A relevant question to consider is whether there could be other province level policy changes that might be correlated with our treatment. We could not identify any such policy that has been rolled out in conjunction with natural gas investments. It is important to note that the central government has the ultimate authority for passing laws and implementing policies related to energy and health in Turkey. Consequently, these policies are either implemented at the national level (e.g., health insurance expansion) or they start as a pilot program and then become effective nationwide. ${ }^{20}$ To account for the possibility of differential investments by the central government at the provincial level, we control for whether the central district mayor of the province is affiliated with the governing political party. Additionally, we control for a full set of region-by-year fixed effects, which should also capture some of these factors.

Note that our identification strategy does not require the levels in infant mortality rates between provinces with and without natural gas to be equal prior to the adoption of natural gas. Rather, it assumes that, in the absence of natural gas adoption, the rates of infant mortality could have trended similarly between the two types of provinces. Although we cannot test this assumption directly, we further assess the credibility of our

\footnotetext{
${ }^{20}$ It can also be argued natural gas adoption and intensity may influence migration decisions of households between provinces without natural gas and those with natural gas. The internal migration decisions are almost entirely determined by economic factors in Turkey and the flow of migration has been from rural to urban provinces in recent decades. To the extent that families migrating into provinces with natural gas are from low socio-economic status, our estimates would be a lower bound. Data on the proportion of migrants by province are available from the TurkStat only for the period 2008-2011. We estimated models of migration as a function of natural gas adoption and expansion along with other control variables. The estimates on the two natural gas variables were both small and imprecisely estimated, suggesting that migration decisions are unrelated to natural gas. These results are available from the authors upon request.
} 
research design by examining whether there are any systematic changes in infant mortality prior to provinces gaining access to natural gas. This can be done using an event study analysis, which would allow us to trace out the trend in the infant mortality rate year-by-year for the periods leading up to and following access to a natural gas infrastructure. In practice, we implement this by estimating a regression of the logarithm of infant mortality rate on a set of indicators for the years to and from the year of adoption of natural gas up to five years, along with province and year fixed effects. The estimates from this analysis, which are shown in Figure 4, suggest no evidence of systematic changes in infant mortality in the years prior to gaining access to a natural gas infrastructure. Therefore, it is unlikely that our results simply reflect continuation of preexisting trends. Next, we plot the logarithm of infant mortality rate against the measure of natural gas intensity net of province and year fixed effects. As shown in Figure 5, the relationship between the infant mortality rate and natural gas intensity has the expected negative sign once province and year fixed effects are accounted for. In addition to province and year fixed effects, we also allow province-specific unobservables to trend differently by controlling for province-specific linear and quadratic time trends in our specifications. Therefore, conditional on the time-variant characteristics, fixed effects, and provincial time trends, we are assessing whether provinces with a more rapid penetration of natural gas have also experienced a more rapid decrease in infant mortality than other provinces. Taken together, Figures 4 and 5 set the stage for our empirical analysis, which is more formally described below. 


\section{Empirical Framework}

If the widespread increase in the consumption of natural gas has indeed led to improvements in infant mortality through reducing air pollution, then we would expect a negative relationship between natural gas intensity and air pollution. In fact, there is evidence to suggest that the increase in natural gas consumption has resulted in a significant reduction in air pollution (Kaygusuz, 2007). Despite such anecdotal evidence, we further motivate our main analysis by estimating a regression model for the impact of the intensity of natural gas on a measure of air pollution, controlling for a set of province characteristics along with province, year, and region-by-year fixed effects. Our air pollution measure is particulate matter $\left(\mathrm{PM}_{10}\right)$, which we obtained from the Turkish Ministry of Health. ${ }^{21}$ The results from this regression are shown in Table A3. The point estimate on the measure of natural gas intensity indicates that a one-percentage point increase in the natural gas services subscription rate is associated with a statistically significant $4 \%$ reduction in the level of particulate matter. This first stage analysis also sets the stage for why natural gas intensity could actually matter for infant mortality.

In order to formally investigate the impact of provincial natural gas adoption on infant mortality, we begin by a reduced form model expressed in the following form: ${ }^{22}$

$$
\log \left(\mathrm{IMR}_{\mathrm{pt}}\right)=\mathrm{X}_{\mathrm{pt}} \beta_{\mathrm{o}}+\beta_{1} \text { Any_Natural_Gas } \mathrm{pt}_{\mathrm{pt}}+\varepsilon_{\mathrm{pt}},
$$

\footnotetext{
${ }^{21}$ Air pollution measure is the averages computed by the provincial meteorology centres. In calculating annual averages, measurements are taken for a minimum of 21 days for each month for at least nine months. Note that we have this measure only for the sub-period of 2002-2010 for an unbalanced panel. However, majority of the missing observations on pollution variables come from the period prior to 2007 . In the end, we have 490 year and province observations on particulate matter. The descriptive statistics in Table 1 indicate that the average levels of particulate matter are lower in provinces that have accessed to a natural gas infrastructure at some point during our analysis period.

${ }^{22}$ Note that equation (1) can be rewritten as $\log \left(\mathrm{IMR}_{\mathrm{pt}}{ }^{*}\right)=\mathrm{X}_{\mathrm{pt}} \beta_{\mathrm{o}}+\beta_{1}$ Any_Natural_Gas $\mathrm{pt}_{\mathrm{pt}}+\mu_{\mathrm{pt}}$, where $\mu_{\mathrm{pt}}=\varepsilon_{\mathrm{pt}}$ $-\log \left(1-\mathrm{k}_{\mathrm{pt}}\right)$. Therefore, as long as $\mathrm{k}_{\mathrm{pt}}$ is uncorrelated with the natural gas indicator, the estimate of $\beta_{1}$ would be unbiased.
} 
where $I M R_{p t}$ represents the infant mortality rate reported for province $p$ and in year $t .^{23}$ $\mathrm{X}_{\mathrm{pt}}$ is a set of exogenous determinants of infant mortality described above. The variable, Any_Natural_Gas $\mathrm{pt}_{\mathrm{p}}$, is a binary indicator for whether the province $\mathrm{p}$ has natural gas in year t. The $\varepsilon_{\mathrm{pt}}$ is the error term. Equation (1) estimates the effect of a binary treatment, which is also the most frequently employed approach in the relevant literature. The coefficient $\beta_{1}$ would measure any permanent shift in infant mortality rate associated with the adoption of natural gas, independent of the intensity of natural gas utilisation in a province. It is important to note that once a province adopts natural gas, the process by which its intensity increases within the province is dynamic, i.e. it evolves gradually over time. However, a specification with a binary natural gas indicator would fail to appropriately capture the dynamic nature of this diffusion process over time, leading to a biased estimate of the actual treatment. ${ }^{24}$ This issue may be particularly important in this case, where the intensity of treatment exposure changes considerably across provinces and over time. Furthermore, policymakers may be interested in the effects of different levels of natural gas intensity, which cannot be discovered by using a binary treatment model. To resolve this issue, we pursue a specification that explicitly models the dynamic

\footnotetext{
${ }^{23}$ It is common to use the log of infant mortality rate as opposed to the level in similar contexts (e.g., Flegg, 1982; Ruhm, 2000; Anand and Baernighausen, 2004; Jamison et al., 2004; Tanaka, 2005; Farahani et al., 2009; Murtin, in press). Those provinces in the treatment category that already have low rates of infant mortality may experience only small improvements in their infant mortality rate in response to the adoption of natural gas. This may be in contrast to provinces with high levels of infant mortality rate, which may experience large swings in infant mortality. However, we also estimate our models using the level of infant mortality rate as the outcome and the results from these models are similar to those presented here and are available from the authors upon request.

${ }^{24}$ As an example, consider the extreme case where every province has a natural gas infrastructure in place, but nobody utilises it as a source of fuel. Since our treatment indicator is defined at the province level, a binary treatment model may fail to reveal the effect of actual utilisation in this case, which should be zero.
} 
nature of the treatment. In this specification we replace the binary indicator of any natural gas in equation (1) with a continuous measure:

$$
\log \left(\mathrm{IMR}_{\mathrm{pt}}\right)=\mathrm{X}_{\mathrm{pt}} \beta_{\mathrm{o}}+\beta_{1} \text { Natural_Gas_Intensity } \mathrm{pt}_{\mathrm{pt}}+\varepsilon_{\mathrm{pt}},
$$

where Natural_Gas_Intensity $\mathrm{pt}_{\mathrm{pt}}$ represents the measure of natural gas intensity defined as the number of natural gas service subscribers per 100 persons in province $\mathrm{p}$ and in year $\mathrm{t}$. The number of subscribers is the total number of household and business units with access to natural gas. The coefficient $\beta_{1}$ would then represent the impact of the rate of natural gas intensity on infant mortality rate. However, the causal interpretation of the coefficient $\beta_{1}$ is complicated due to omitted variables that are likely to be correlated with both the availability of natural gas infrastructure and infant mortality. For example, as shown in Table 1, provinces with natural gas infrastructure are more likely to be urban, industrial, and with more motor vehicles per capita. Therefore, these provinces may also have higher levels of infant mortality despite gaining access to a natural gas infrastructure. In order to control for the impact of these factors, we rely on the longitudinal nature of our data and incorporate a series of fixed effects into equation (2):

$$
\log \left(\mathrm{IMR}_{\mathrm{pt}}\right)=\mathrm{X}_{\mathrm{pt}} \beta_{0}+\beta_{1} \text { Natural_Gas_Intensity }{ }_{\mathrm{pt}}+\omega_{\mathrm{p}}+\lambda_{\mathrm{t}}+\tau_{\mathrm{pt}}+\tau_{\mathrm{pt}}^{2}+\varepsilon_{\mathrm{pt}}
$$

where $\omega_{\mathrm{p}}$ is a set of province fixed effects that would capture any permanent differences across provinces and $\lambda_{t}$ is set of year fixed effects that would account for any unobserved factors common to all provinces. It is important to note that if Natural Gas Intensity 
properly captures the dynamic nature of the treatment, then the estimate of $\beta_{1}$ should not be sensitive to controlling for province-specific trends as there would be little variation left for these trends to capture or any remaining variation would be uncorrelated with the intensity measure. Despite our prediction, we estimate specifications that control for province-specific linear and quadratic time trends as denoted by $\tau_{\mathrm{pt}}$ and $\tau_{\mathrm{pt}}^{2}$ in equation (3). Finally, we further enrich the specification in equation (3) by controlling for regionby-year fixed effects that would account for any spill overs to neighbouring provinces as well as any time-variant differences in unobserved heterogeneity that are common to provinces within a region. ${ }^{25}$

\section{Results}

We begin by presenting the estimates of the impact of Any Natural Gas on the logarithm of infant mortality rate in Table 6. Column (1) presents the estimate for the binary indicator of any natural gas adoption on infant mortality without any control variables. Column (2) adds year fixed effects and column (3) incorporates both year and province fixed effects that control for permanent differences across provinces. In columns (4) and (5), we add province-specific linear and quadratic time trends, respectively, and in

${ }^{25}$ The heavier economic activity in certain regions like Marmara, which includes major urban and industrial hubs like Istanbul, Bursa, and Kocaeli, may have spillover effects on all the other provinces within that region. For example, Bursa and Istanbul are connected to each other through highly congested routes that have to pass through Yalova, a smaller and less urban province within the same region. Therefore, any air pollution, for example caused by the traffic congestion between Bursa and Istanbul, may also contaminate the air in Yalova. Controlling for region-by-year fixed effects would mitigate concerns about the aggregate impact of these factors. As mentioned previously, the capital expenditures for natural gas network expansions are provided by the central government. Due to economies of scale, provinces within a particular region may gain access to a natural gas infrastructure as a cluster or soon after each other, though we do not see such a pattern in Table A1. It is also possible that households in regions experiencing rapid economic growth may collectively advocate for increased natural gas availability in their regions. Therefore, in addition to accounting for regional income shocks, controlling for region specific time dummies would also account for factors such as the availability and expansions of natural gas networks at the regional level. 
column (6) we control for time-varying province characteristics. Finally, in column (7) we show estimates from a specification that also accounts for region-by-year fixed effects. Standard errors are robust to any form of heteroscedasticity and clustered at the province level to allow for correlation within a province (Bertrand et al., 2004).

The estimates in the first two columns of Table 6 are positive, suggesting that natural gas infrastructure is positively correlated with infant mortality. This is consistent with the earlier evidence that we presented, and suggests that provinces with and without natural gas infrastructure differ in ways that are correlated with infant mortality. For example, provinces with natural gas are more likely to be urban and industrial than others. Since urbanisation and industrialisation are likely to be positively correlated with infant mortality, failing to control for these differences would cause the estimate on any natural gas indicator to be biased downward, and like in our case, to possibly to switch sign. As expected, accounting for permanent province characteristics in column (3) makes a dramatic impact on the estimate of the effect of any natural gas and causes its sign to switch to negative. Specifically, once we control for province fixed effects, having access to a natural gas infrastructure is associated with a $27.1 \%$ decrease in the infant mortality rate. However, as we explained in the previous section, it is unlikely that this estimate actually draws an accurate picture of a treatment whose dosage increases gradually. In fact, it becomes small in size and statistically insignificant when we add province-specific linear and quadratic time trends in columns (4) and (5). At first glance, the finding that the estimate on the binary natural gas indicator is sensitive to the inclusion of province-specific trends appears to be at odds with the notion that the timing of the adoption of natural gas is exogenous. However, the dynamic nature of the 
treatment (i.e., gradual increase in the intensity of natural gas use) is unlikely to be accounted for by a binary treatment model. ${ }^{26}$ Therefore, province-specific trends are likely to capture not only the differences in pre-existing trends across provinces, but also the differences in the diffusion of the natural gas intensity subsequent to the adoption of natural gas. ${ }^{27}$ As a result, the coefficient on the any natural gas indicator in this specification is likely to be a biased estimate of its counterfactual.

This takes us to our preferred specification, which replaces the binary indicator of any natural gas with the continuous natural gas intensity measure. The results from the dynamic response model are presented in Table $7 .{ }^{28}$ Similar to the results presented in Table 6 , the estimate on the natural gas intensity variable is still positive and statistically significant in columns (1) and (2). However, once province fixed effects are controlled for in column (3), the estimate switches sign and becomes negative in line with our predictions. In the following two columns, we present estimates from specifications, which successively add province-specific linear and quadratic trends. Consistent with our predictions earlier, allowing for differential trends in the infant mortality rate across provinces does not cause any appreciable change to the estimate on the impact of natural gas intensity. According to the point estimate in column (5), a one-percentage point increase in the natural gas intensity would lower the infant mortality rate by $4.1 \%$.

If our identification strategy is credible, then the province fixed effects and trends should capture all of the time-variant and -invariant factors correlated with both natural gas intensity and infant mortality. Therefore, as indicated by Tables 2 through 5 , adding

\footnotetext{
${ }^{26} \mathrm{We}$ thank an anonymous referee for pointing this out.

${ }^{27}$ Note that this problem is similar to the one in Wolfers (2006), who examines the impact of unilateral divorce laws on divorce rates.

${ }^{28} \mathrm{We}$ also estimated weighted regressions using the mean population density and birth density as weights. These estimations, shown in Table A4, did not cause any appreciable changes to the results presented here.
} 
time-variant characteristics of provinces should not cause any appreciable changes to our estimates. As shown in column (6), this is indeed the case in our analysis. In particular, controlling for a comprehensive set of time-varying differences across provinces does not change the estimate on the impact of natural gas intensity on infant mortality. In essence, once permanent differences across provinces are accounted for, the natural gas intensity can be considered as a natural experiment. Finally, in column (7) we present the results from a specification that also controls for region-by-year fixed effects along with all the other variables included in the previous columns. Controlling for region-by-year fixed effects is likely to help mitigate the impact of positive spillovers on air quality enjoyed by provinces without natural gas that are bordered to provinces in the treatment group as well as to account for any differences in governmental policies implemented at the regional level, such as healthcare interventions and university research hospitals that typically serve entire regions. As it turns out, controlling for region-by-year fixed effects leaves the estimated coefficient on natural gas intensity unaffected. In particular, the coefficient estimate presented in column (7) indicates that the effect of natural gas intensity on the rate of infant mortality is $4 \%$.

Next we conduct some back of the envelope calculations to put these estimates into context. For instance, as shown in Table 1, the average natural gas intensity is 7.9 per 100 persons in province-year observations with a natural gas infrastructure. In 2011, there were 8,714 infant deaths for $1,087,933$ births in the provinces with a natural gas infrastructure, resulting in an infant mortality rate of about 8 per 1,000 births. Holding the number of births constant, this would suggest that there could be approximately 348 
fewer infant deaths in these provinces in 2011 in response to a one-percentage point increase in the natural gas intensity.

\subsection{Robustness and Sensitivity Analyses}

The results presented above could be driven by both a decrease in the numerator (number of children who die in their first year) and an increase in the denominator (the number of live births). For example, the infant mortality rate could go down due to an increase in the denominator if the natural gas adoption is associated with an increase in the overall quality of health care services. As explained previously, this is unlikely since we control for the number of hospitals and hospital beds per capita along with the number of physicians per capita and an indicator for whether the province implements a family physician program. Furthermore, province level linear and quadratic trends should also help gauge these effects. Another possibility is that the improvements in air quality might lead to a reduction in the number of stillbirths and miscarriages, which would then result in an increase in the number of live births. We test this hypothesis by estimating our models with the logarithm of infant deaths as the dependent variable and the logarithm of births as an additional control variable (Arceo-Gomez et al., 2012). As presented in Panel A of Table 8, performing this test yields estimates that are largely consistent with those in Table 7 when province fixed effects, province-specific linear and quadratic time trends and region-by-year fixed-effects are specified. Therefore, it is unlikely that our results are driven by an increase in births. Next, we estimate models using the logarithm of births as the outcome. As shown in Panel B of Table 8, the estimates in specifications from columns (3) to (7) are all zero, suggesting that natural gas adoption does not have an effect on the number of babies born. 
Note that we use data from all 81 Turkish provinces in our analysis. Among these provinces, 20 of them have never gained access to a natural gas infrastructure during the period of our analysis. To test for the possibility that there is something fundamentally different about these provinces that might be affecting our results, we estimate our models excluding these provinces from the analysis. Results from the estimation of these models are presented in Panel A of Table 9. The pattern obtained here is indistinguishable from the one in Table 7. Specifically, the estimate in our richest specification shown in column (7) is -0.041 , which is nearly identical to the one in Table 7.

Next we assess whether our results are driven by provinces, which have always had natural gas during the period of our analysis. In the first test, we estimate our models by excluding Istanbul, which, with its 13.5 million citizens, accounts for over $18 \%$ of Turkey's total population. ${ }^{29}$ As shown in Panel B of Table 9, the results again remain almost identical to those in Table 7 when we perform this exercise. In Panel C, we repeat the same test by excluding, Ankara, Bursa, Eskisehir, Istanbul and Kocaeli, which are the provinces that have always had access to natural gas during our analysis period. Again, excluding these provinces from our analysis does not affect the estimate on the natural gas intensity. Taken together, results presented in Table 9 suggest that the main finding

\footnotetext{
${ }^{29}$ Istanbul is also one of the largest urban and busiest agglomerations in the world and responsible for over a quarter of Turkey's GDP. Concurrent with the expansion of natural gas infrastructure, Istanbul has experienced a rapid transformation in a multitude of dimensions during the period of our analysis. For example, it experienced a surge in the number of private hospitals, which doubled in numbers between 2000 and 2005. Although we control for a number of variables related to the capacity and quality of health delivery services in our models, it can still be argued that there remain other related factors that might have coincided with the expansion of natural gas services. One particular candidate is the mass-transit underground railway network, which entered service in 2000 and has caused a major relief in traffic congestion. Then the question is whether and to what extent the control variables and various fixed effects in our models account for these developments in a potential outlier like Istanbul.
} 
obtained in Table 7 is not driven by any systematic differences between provinces with and without natural gas.

The specifications we discuss above assume that the natural gas intensity is linearly related to the infant mortality rate. However, this does not have to be the case if, for example, reductions in air pollution are more beneficial at higher levels of air pollution than lower levels of pollution. Then any gains in infant mortality associated with the intensity of natural gas use may be higher at the early stages of adoption to natural gas than later stages. To assess the possibility of a non-linear relationship between natural gas intensity and infant mortality rate, we estimate our main specification with both linear and quadratic measures of natural gas intensity. This exercise does not change any of the implications of the previously discussed results. Specifically, the estimates on the linear and quadratic terms for natural gas intensity in the most comprehensive specification (column 7) are -0.061 and 0.001 , respectively, where only the former is statistically significant at the $10 \%$ level. Given that the quadratic term is zero in both economical and statistical terms, the causal relationship between natural gas intensity and infant mortality rate is likely to be a linear one.

Note that our intensity of natural gas variable is defined as the number of subscribers to natural gas services per 100 persons. It may be argued that it would be more informative to produce estimates based on a measure of natural gas intensity using the number of households in a given province and year. Unfortunately, the TurkStat sources provide information on the province level household figures only for 2000 and 2011. Nevertheless, we generated proxy figures for the province level household numbers for each of the 81 province for all other years assuming that the rate of growth for the 
number of household is linear over time. Using these proxy figures, we then constructed a measure of natural gas intensity per 100 households and estimated our main specification with this new measure. Results from this exercise do not change any of the implications presented above. More specifically, the estimate on the proxy measure of subscribers per 100 households is $-0.011(\mathrm{p}=0.05)$, suggesting that a $1 \%$ increase in the natural gas intensity per 100 households would lead to a $1.1 \%$ decrease in infant mortality rate. If there are approximately 3 to 4 persons per household, then the effect size of 1.1, which is roughly a quarter of the magnitude of our main estimate, is sensible.

A closer look over Figures 1 and 2 reveals that province level natural gas subscriptions rate exhibited a tenfold increase among the provinces with natural gas between 2001 and 2011, and these increases mainly took place after 2005. Accordingly, if we take 2001 as the reference year, the effect of natural gas intensity on the rate of infant mortality should be relatively greater towards the end of the analysis period (e.g., 2011) in comparison to a time when provinces had just started to adopt natural gas (i.e., 2005). To explore whether this is the case, we re-estimate our models by using two data points as the initial and end dates for each province for the periods 2001-05, 2001-07, 2001-09, and 2001-11, respectively. This implementation is similar to the long-difference estimate used in several other studies (e.g., Acemoglu and Johnson, 2007) and would allow us to further test whether our results are driven by the systematic differences between provinces with and without natural gas. Specifically, if the long-difference estimates between 2001 and the middle of the analysis period (i.e., 2005 or 2007) are similar to the long-difference estimates between 2001 and the end of the analysis period (i.e., 2009 or 2011), then it is possible that our results reflect a combination of factors that 
make the two types of provinces different from each other in ways correlated with infant mortality. In line with our prediction, the estimates on natural gas intensity are small (0.004 and -0.013 ) and neither are significant when we consider 2005 or 2007 as the end points of the analysis. However, the estimate becomes larger and significant as we approach towards the end of our analysis period. For example, if we consider 2009 and 2011 as our end points, the long-difference estimates on natural gas intensity are -0.044 and -0.049 .

\section{Discussion and Conclusions}

Industrialisation and economic development have brought with it dramatic improvements in living conditions of vast populations in developing countries through higher incomes and better health care. However, these benefits have come at the substantial cost of deterioration in environmental conditions and air quality, which threatens some of the gains achieved by these countries. Furthermore, there are very few viable policy options or enforcement mechanisms available to developed countries or international environmental organisations that could induce developing countries to take meaningful steps toward addressing environmental problems. One policy instrument commonly used to control air pollution is regulations. However, there are serious challenges to implementing regulations successfully, especially in developing countries, due to weak governance and corruption problems. Furthermore, concerns over global climate change are often side-lined in these countries due to a strong desire to maintain robust economic growth. Under these circumstances, natural gas has emerged as an increasingly attractive 
source of fuel and one that could help efforts to limit carbon emissions globally without causing interruptions in the mounting energy needs of these countries in the short run.

In this paper, we consider the impact of widespread expansion of natural gas services for residential and commercial use on the rate of infant mortality in Turkey. To identify this impact, we utilise the variation in the timing of deployment and intensity of expansion of natural gas infrastructures across Turkish provinces between 2001 and 2011. Our results indicate that the expansion of natural gas services has led to a significant reduction in the rate of infant mortality. The estimate from our most comprehensive specification indicates that a one-percentage point increase in the rate of subscriptions to natural gas services would cause the infant mortality rate to decrease by $4 \%$.

The estimates from the first stage, i.e., the impact of natural gas intensity on particulate matter, and the reduced form, i.e., the impact of natural gas intensity on the rate of infant mortality, can be combined together to produce an instrumental variables estimate of the structural relationship between air pollution and infant mortality. In particular, $\partial \log (\mathrm{IMR}) / \partial \mathrm{PM}_{10}$ can be rewritten as $[\partial \log (\mathrm{IMR}) / \partial($ Natural Gas Intensity) $] /\left[\partial \mathrm{PM}_{10} / \partial\right.$ (Natural Gas Intensity)]. As shown in Table 7 and Table A3, both the numerator and the denominator on the right-hand-side of this expression are close to 0.04 suggesting that the elasticity estimate for the IMR with respect to $\mathrm{PM}_{10}$ is close to unity. It is important to note that the validity of the instrumental variables estimate hinges on the assumption that the expansion of natural gas networks can only affect infant mortality through its effect on air pollution once time-varying province characteristics and fixed effects are controlled for. This assumption would be violated if 
other factors exist, such as energy prices or other unmeasured air pollutants that might be influenced by natural gas expansion. To the extent that these factors are not accounted for by our controls, the IV estimate would be biased. Therefore, the IV estimate should be viewed only as suggestive and caution must be exercised in its interpretation. Keeping this limitation in mind, we next compare our elasticity estimate to those obtained in several previous studies. For example, our estimate is particularly consistent with that of Tanaka (2012), who reports an elasticity of 0.95 for particulate matter in a study of the impact of air pollution on infant mortality in China. Focusing on the estimates derived from the United State context, the elasticity estimates for particulate matter documented by Chay and Greenstone (2003a), Currie and Neidell (2005), and Currie et al. (2009) are $0.285,0.001$, and -0.008 , respectively ${ }^{30}$ In a recent study focusing on Mexico, ArceoGomez et al. (2012) find an elasticity of 0.42 for particulate matter, which is smaller than our estimate, but larger than those generally reported for the United States. To the extent that our estimate is larger than those reported by studies using data from the United States and consistent with those obtained for China, and to some extent, Mexico, the number of lives of infants saved due to improved air quality is likely to be higher in the developing countries than it is in the developed countries. ${ }^{31}$

The results in this paper are especially useful in light of the ongoing public and political debate about the future of fracking revolution that has recently started in the United States and is now spreading elsewhere. Advocates argue that there may be real environmental benefits to fracking because natural gas replaces dirty coal. As suggested by our findings, the health benefits of widespread replacement of coal by natural gas can

\footnotetext{
${ }^{30}$ These figures are obtained from Table 8 in Arceo-Gomes et al. (2012).

${ }^{31}$ One exception is Knittel et al. (2011), who find an effect corresponding to an elasticity of 1.88 in a study of the impact of air pollution on infant mortality in California.
} 
indeed be nontrivial. However, fracking has also its sharp critiques, who worry about the potential negative impacts of this practice on the environment. Until the environmental consequences of fracking are fully assessed, the net effect of this practice on health will remain ambiguous.

Resul Cesur - University of Connecticut

Erdal Tekin - American University, IZA, and NBER

Aydogan Ulker - Deakin University 


\section{References}

Acemoglu, D. and Johnson, S. (2007). 'Disease and development: The effect of life expectancy on economic growth', Journal of Political Economy, vol. 115(6), pp. 925-85.

Acemoglu, D., Aghion, P., Bursztyn, L. and Hemous, D. (2012). 'The environment and directed technical change', American Economic Review, 102(1), pp. 131-66.

Anand, S. and Baernighausen, T. (2004). 'Human resources and health outcomes: crosscountry econometric study', Lancet, vol. 364, pp. 1603-9.

Anderson, B.A. and Silver, B.D. (1986). 'Infant mortality in the Soviet Union: Regional differences and measurement issues', Population and Development Review, vol. 12(4), pp. 705-38.

Anthopolos, R. and Becker, C.M. (2010). 'Global infant mortality: Correcting for undercounting', World Development, vol. 38(4), pp. 467-81.

Aras, H. and Aras, N. (2005). 'Eskişehir'de konutsal doğal gaz talebine ekonomik göstergelerin ve diş ortam sıcaklığının etkileri', Mühendis ve Makine Dergisi, vol. 46(540), pp. 20-7.

Arceo-Gomez, E. O., Hanna, R. and Oliva, P. (2012). 'Does the effect of pollution on infant mortality differ between developing and developed countries? Evidence from Mexico City', NBER Working Paper No.18349.

Becker, C.M., Bibosunova, D., Holmes, G. and Ibragimova, M. (1998). 'Maternal care vs. economic wealth and the health of newborns: Bishkek, Kyrgyz Republic and Kansas City, USA', World Development, vol. 26(11), pp. 2057-72.

Bertrand, M., Duflo, E.and Mullainathan, S. (2004). 'How much should we trust differences-in-differences estimates?' Quarterly Journal of Economics, vol. 119(1), pp. 249-75.

Caulton, D., Shepson, B., Santoro, R., Sparks, J., Howarth, R., Ingraffea, A., Cambaliza, M., Sweeney, C., Karion, A., Davis, K., Stirm, B., Montzka, S. and Miller, B. (2014). 'Toward a better understanding and quantification of methane emissions from shale gas development', Proceedings of the National Academy of Science of the United States of America, vol. 111(17), pp. 6237-42.

Chay, K. and Greenstone, M. (2003a). 'The Impact of air pollution on infant mortality: Evidence from geographic variation in pollution shocks induced by a recession', Quarterly Journal of Economics, vol. 118, pp. 1121-67.

Chay, K. and Greenstone, M. (2003b). 'Air quality, infant mortality, and the Clean Air Act of 1970', NBER Working Paper No. 10053. 
Currie, J., Greenstone, M. and Moretti, E. (2011). 'Superfund cleanups and infant health', American Economic Review, vol. 101(3), pp. 435-41.

Currie, J. and Neidell, M. (2005). 'Air pollution and infant health: What can we learn from California's recent experience?', Quarterly Journal of Economics, vol. 120(3), pp. 1003-30.

Currie, J., Neidell, M. and Schmieder, J. F. (2009). 'Air pollution and infant health: Lessons from New Jersey’, Journal of Health Economics, vol. 28(3), pp. 688-703.

Currie, J. and Walker, R. (2011). 'Traffic congestion and infant health: Evidence from EZPass', American Economic Journal: Applied Economics, vol. 3(1), pp. 65-90.

Dejmek, J., Solanský, I., Benes, I., Lenícek, J. and Srám, R. J. (2000). 'The impact of polycyclic aromatic hydrocarbons and fine particles on pregnancy outcome', Environmental Health Perspectives, vol. 108(12), pp. 1159-64.

Farahani, M., Subramanian, S. and Canning, D. (2009). 'The effect of changes in health sector resources on infant mortality in the short-run and the long-run: A longitudinal econometric analysis', Social Science \& Medicine, vol. 68(11), pp. 1918-25.

Finkel, M.L. (2011). 'The rush to drill for natural gas: a public health cautionary tale', American Journal of Public Health, vol. 101(5), pp. 784-5.

Flegg, A.T. (1982). 'Inequality of income, illiteracy and medical care as determinants of infant mortality in underdeveloped countries', Population Studies, vol. 36, pp. 441-58.

Greenstone, M. and Hanna, R. (in press). 'Environmental regulations, air and water pollution, and infant mortality in India', forthcoming in American Economic.

Gruber, J., Hendren, N. and Townsend, R.M. (2014). 'The great equaliser: Health care access and infant mortality in Thailand', American Economic Journal: Applied Economics, vol. 6(1), pp. 91-107.

Ha, E.H., Hong, Y.C., Lee, B.E., Woo, B.H., Schwartz, J. and Christiani, D.C. (2001). 'Is air pollution a risk factor for low birth weight in Seoul?', Epidemiology, vol. 12(6), pp. 643-8.

International Energy Agency. (2009). Natural Gas Information 2009. Paris: OECD/IEA

International Energy Agency. (2011). Natural Gas Information 2011. Paris: OECD/IEA.

International Energy Agency. (2012). Natural Gas Information 2012. Paris: OECD/IEA. 
Jamison, D., Sandbu, M. and Wang, J. (2004). 'Why Has Infant Mortality Decreased at Such Different Rates in Different Countries?', Disease Control Priorities Project.

Jayachandran, S. (2009). 'Air quality and early-life mortality: evidence from Indonesia's wildfires', Journal of Human Resources, vol. 44(4), pp. 916-54.

Kaygusuz, K. (2007). 'Energy use and air pollution issues in Turkey', CLEAN-Soil, Air, Water, vol. 35(6), pp. 539-47.

Knittel, C, Miller, D.L. and Sanders, N.J. (2011). 'Caution, drivers! Children present: Traffic, pollution, and infant Health', NBER Working Paper No. 17222.

Krupp, F. (2014). 'Don't just drill baby. Drill carefully: How to making fracking safer for the environment', Foreign Affairs, May-June issue. Retrieved from http://www.foreignaffairs.com/articles/141204/fred-krupp/dont-just-drill-baby-drillcarefully (last accessed: 9 March 2015).

Li, N., Sioutas, C., Cho, A., Schmitz, D., Misra, C., Sempf, J. and Nel, A. (2003). 'Ultrafine particulate pollutants induce oxidative stress and mitochondrial damage', Environmental Health Perspectives, vol. 111(4), pp. 455-60.

Lopez, A., Ahmad, O., Guillot, M., Inoue, M., Ferguson, B. and Salomon, J. (2001). Health Systems Performance Assessment Peer Review Technical Documentation. IV Outcomes: Population Health - Life tables for 191 countries for 2000: data, methods, results. World Health Organisation: Evidence and Information for Policy.

Maisonet, M., Correa, A., Misra, D. and Jaakkola, J.J.K. (2004). 'A review of the literature on the effects of ambient air pollution on fetal growth', Environmental Research, vol. 95(1), pp. 106-15.

Mash, R., Minnaar, J. and Mash, B. (2014). 'Health and fracking: Should the medical profession be concerned', Medicine and the Environment, vol. 104(5), pp. 332-5.

Mitka, M. (2012). 'Rigorous evidence slim for determining health risks from natural gas fracking', Journal of the American Medical Association, vol. 307(20), pp. 2135-6.

Morse, E. (2014). 'Welcome to the revolution: Why shale is the next shale', Foreign Affairs, May-June issue. Retrieved from http://www.foreignaffairs.com/articles/141202/edward-1-morse/welcome-to-therevolution (last accessed: 9 March 2015).

Murtin, F. (in press). 'Long-term Determinants of the Demographic Transition: 18702000', forthcoming in Review of Economics and Statistics. 
Paltsev, S., Jacoby, H.D., Reilly, J.M., Ejaz, Q.J., O’Sullivan, F., Morris, J., Rausch, S., Winchester, N. and Kragha, O. (2011). 'The future of U.S. natural gas production, use, and trade', Energy Policy, vol. 38(9), pp. 5309-12.

Podesta, J.D. and Wirth, T.E. (2009). Natural Gas: A Bridge Fuel for the 21st Century. Center for American Progress.

Ruhm, C. (2000). 'Parental leave and child health', Journal of Health Economics, vol. 19(6), pp. 931-60.

Siddiqui, A.R., Gold, E.B., Yang, X., Lee, K., Brown, K.H. and Bhutta, Z.A. (2008). 'Prenatal exposure to wood fuel smoke and low birth weight', Environmental Health Perspectives, vol. 116(4), pp. 543-9.

Tanaka, Sakiko. (2005). 'Parental leave and child health across OECD countries', Economic Journal, vol. 115(501), pp. F7-F28.

Tanaka, Shinsuke. (2012). 'Environmental regulations on air pollution in China and their impact on infant mortality', Working Paper, Hiroshima University, Graduate School for International Development and Cooperation (IDEC).

Tangcharoensathien, V., Faramnuayphol, P., Teokul, W., Bundhamcharoen, K. and Wibulpholprasert, S. (2006). 'A critical assessment of mortality statistics in Thailand: potential for improvements', Bulletin of the World Health Organisation, vol. 84(3), pp. 233-8.

Victora, C.G. and Barros, F.C. (2001). 'Infant mortality due to perinatal causes in Brazil: trends, regional patterns and possible interventions', Sao Paolo Medical Journal, vol. 191(1), pp. 33-42.

Wolfers, J. (2006). "Did unilateral divorce laws raise divorce rates? A reconciliation and new results." American Economic Review, vol. 96(5), pp. 1802-20. 
Fig. 1. Number of Provinces with Natural Gas Infrastructure

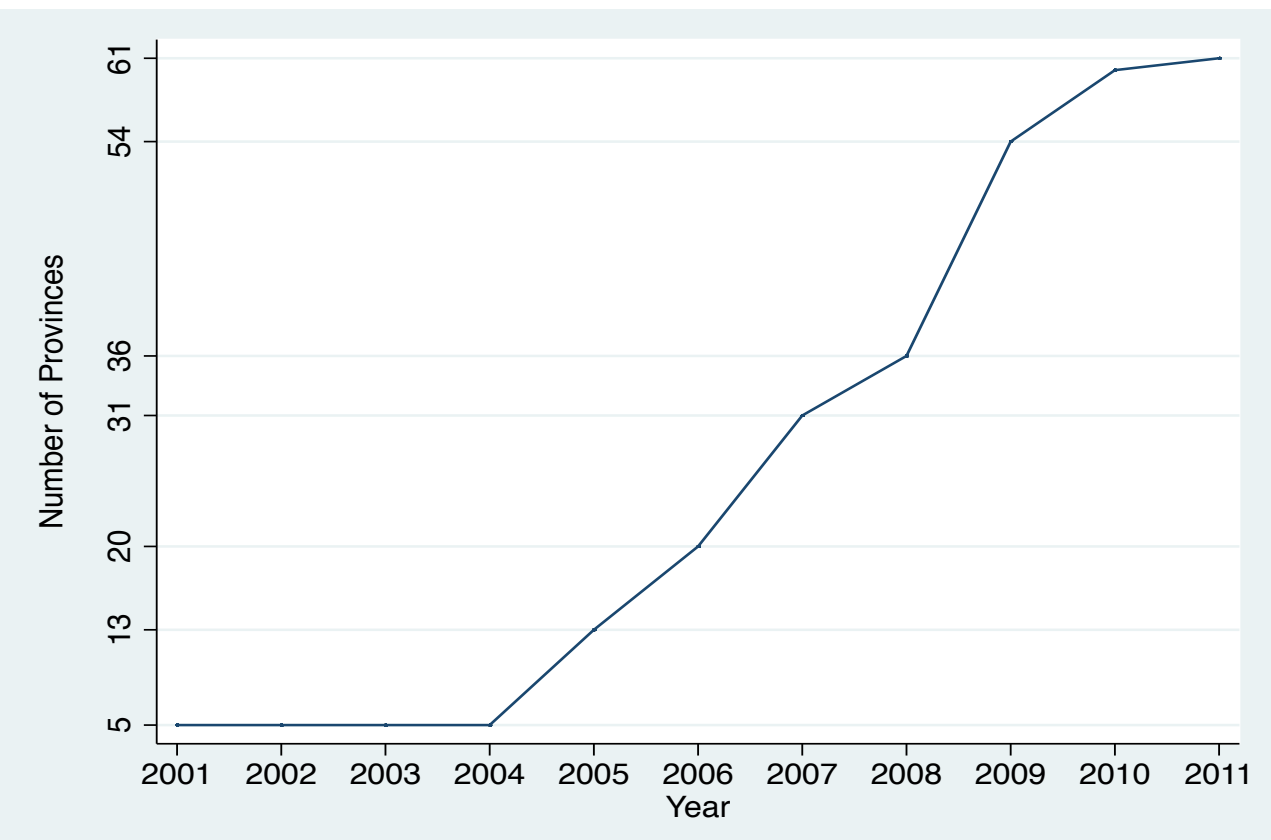

Note: There are 81 provinces in Turkey

Source: Natural Gas Journal

Fig. 2. The Number of Subscriptions to Natural Gas

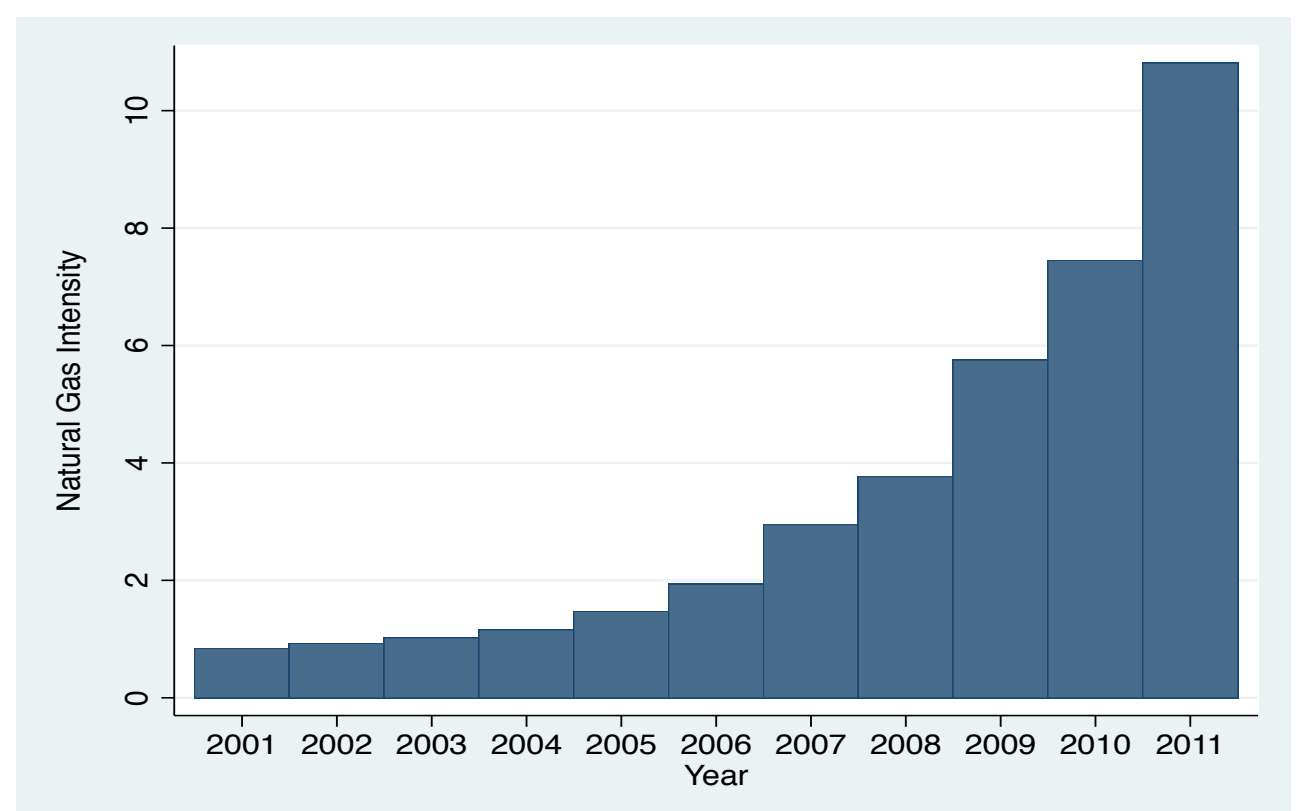

Note: Natural Gas Intensity is defined as natural gas subscribers per 100 populations. The sample consists of provinces with access to natural gas services for at least one year during the period of 2001-2011. Source: Natural Gas Journal 
Fig. 3. Natural Gas Intensity in Select Provinces
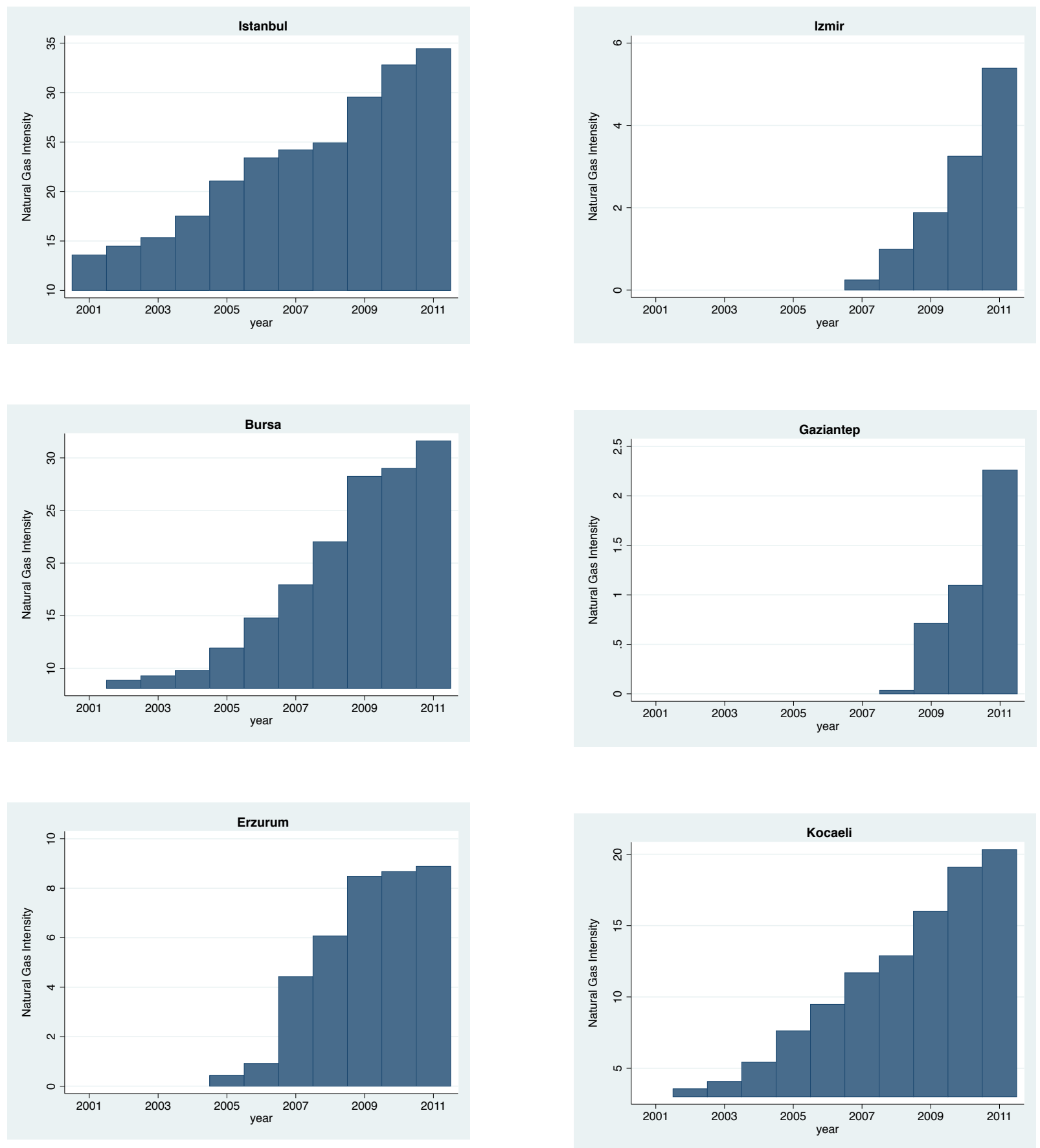

Source: Natural Gas Journal. 
Fig. 4. Event Study Estimates of the Effect of Any Natural Gas on Log Infant Mortality Rate

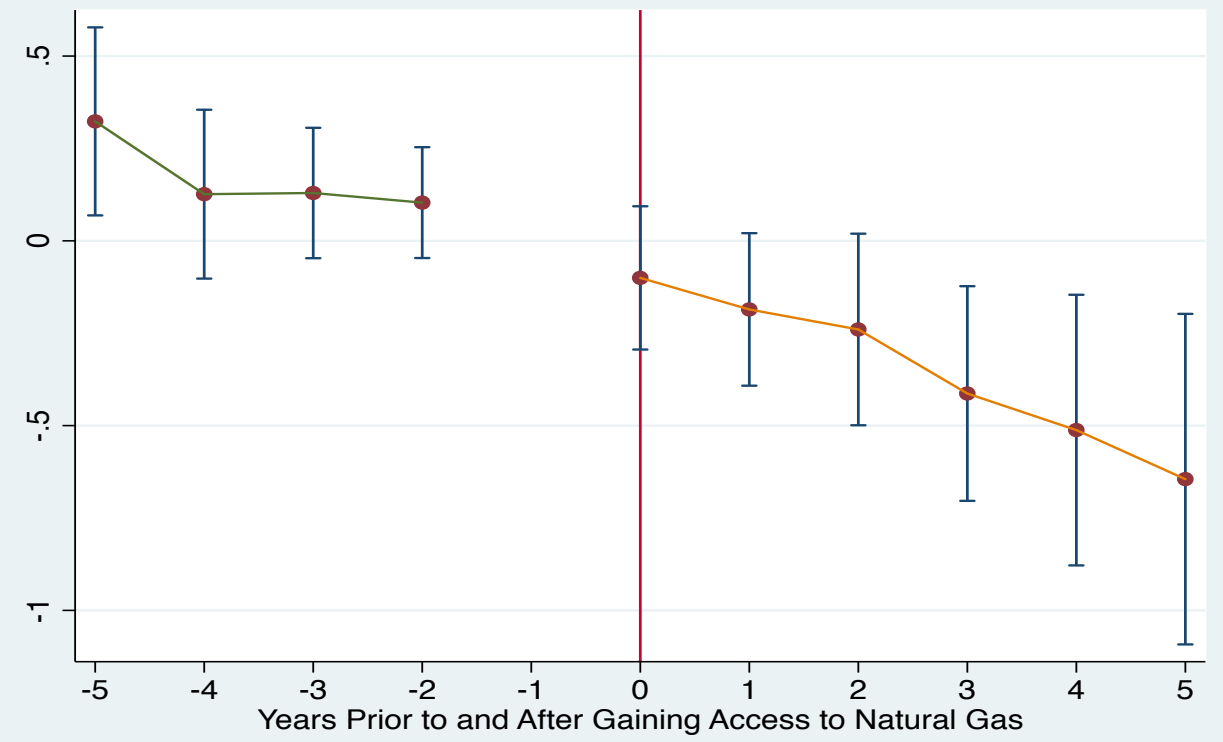

The figure displays coefficients and $95 \%$ confidence intervals. The reference category is one" "year prior to gaining access to natural gas.

Fig. 5. Log Infant Mortality vs. Natural Gas Intensity, Net of Province and Year Fixed Effects

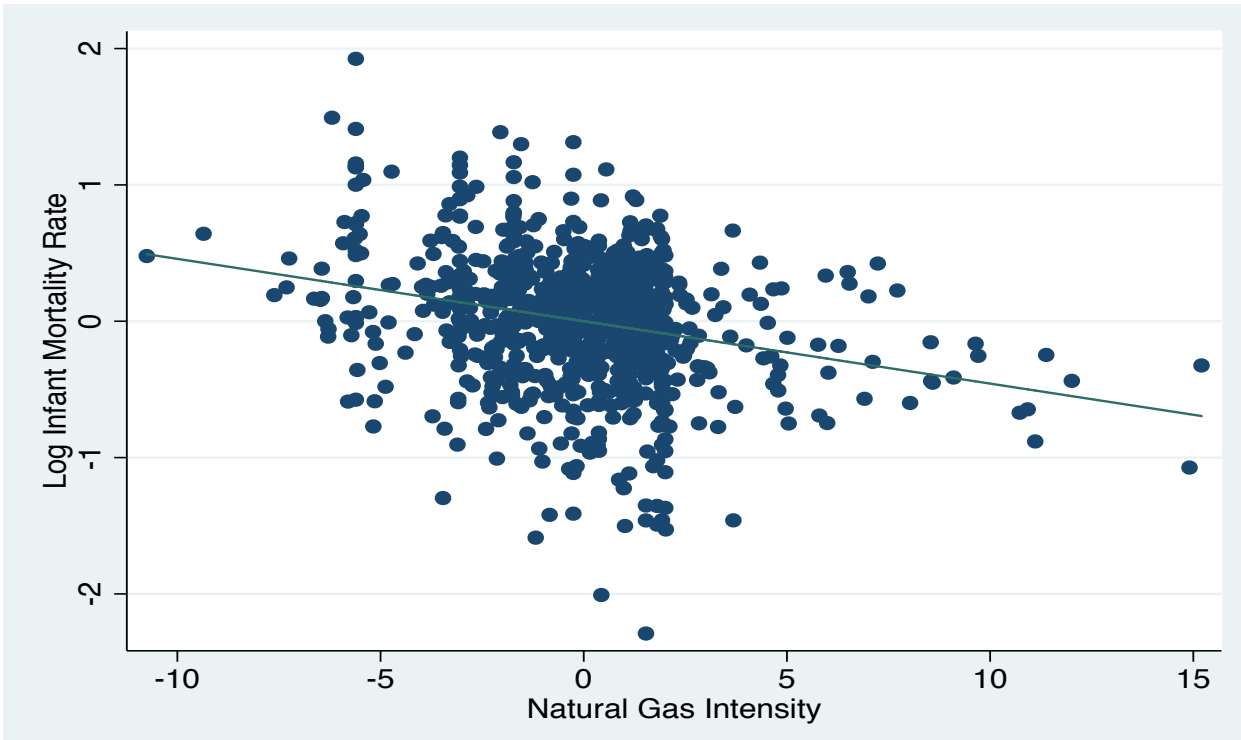


Table 1

Descriptive Statistics

\begin{tabular}{|c|c|c|c|c|c|}
\hline Variable & $\begin{array}{c}(1) \\
\text { ALL }\end{array}$ & $\begin{array}{c}\text { (2) } \\
\text { Any } \\
\text { Natural } \\
\text { Gas }=0\end{array}$ & $\begin{array}{c}(3) \\
\text { Any } \\
\text { Natural } \\
\text { Gas =1 }\end{array}$ & $\begin{array}{c}(4) \\
\text { Ever Had } \\
\text { Natural } \\
\text { Gas }=0\end{array}$ & $\begin{array}{c}(5) \\
\text { Ever Had } \\
\text { Natural } \\
\text { Gas }=1\end{array}$ \\
\hline Infant Mortality per Thousand Births & $\begin{array}{c}9.176 \\
(5.387)\end{array}$ & $\begin{array}{c}8.166 \\
(6.240)\end{array}$ & $\begin{array}{c}10.029 * * * \\
(4.732)\end{array}$ & $\begin{array}{c}3.217 \\
(2.363)\end{array}$ & $\begin{array}{c}9.829 * * * \\
(5.222)\end{array}$ \\
\hline Any Natural Gas & $\begin{array}{c}0.336 \\
(0.473)\end{array}$ & --- & -- & -- & $\begin{array}{c}0.442 \\
(0.497)\end{array}$ \\
\hline Natural Gas Intensity & $\begin{array}{l}2.648 \\
(6.142)\end{array}$ & --- & $\begin{array}{c}7.871 \\
(8.435)\end{array}$ & --- & $\begin{array}{c}3.476 \\
(6.831)\end{array}$ \\
\hline Ever Had Natural Gas & $\begin{array}{c}0.762 \\
(0.426)\end{array}$ & $\begin{array}{c}0.641 \\
(0.480)\end{array}$ & --- & --- & -- \\
\hline Average Particulate Matter $\left(\mu \mathrm{g} / \mathrm{m}^{3}\right)$ & $\begin{array}{c}66.194 \\
(30.611)\end{array}$ & $\begin{array}{c}62.712 \\
(34.188)\end{array}$ & $\begin{array}{c}70.611 * * * \\
(24.739)\end{array}$ & $\begin{array}{c}78.941 \\
(37.151)\end{array}$ & $\begin{array}{c}63.519 * * * \\
(28.388)\end{array}$ \\
\hline Hospitals Per-100 K Population & $\begin{array}{c}2.063 \\
(0.924)\end{array}$ & $\begin{array}{c}2.052 \\
(0.982)\end{array}$ & $\begin{array}{c}2.089 \\
(0.767)\end{array}$ & $\begin{array}{c}2.185 \\
(1.158)\end{array}$ & $\begin{array}{c}2.025 * * * \\
(0.835)\end{array}$ \\
\hline Hospital Beds Per-100 K Population & $\begin{array}{l}214.041 \\
(90.357)\end{array}$ & $\begin{array}{l}196.613 \\
(88.541)\end{array}$ & $\begin{array}{c}255.971 * * * \\
(80.520)\end{array}$ & $\begin{array}{l}159.178 \\
(76.415)\end{array}$ & $\begin{array}{c}231.214 * * * \\
(87.544)\end{array}$ \\
\hline Physicians Per-100 K Population & $\begin{array}{l}125.472 \\
(51.076)\end{array}$ & $\begin{array}{l}107.555 \\
(39.063)\end{array}$ & $\begin{array}{c}143.210^{* * *} \\
(55.300)\end{array}$ & $\begin{array}{c}94.378 \\
(23.170)\end{array}$ & $\begin{array}{c}135.426 * * * \\
(53.535)\end{array}$ \\
\hline Per-capita Regional GDP & $\begin{array}{c}7.770 \\
(3.458)\end{array}$ & $\begin{array}{c}6.768 \\
(2.835)\end{array}$ & $\begin{array}{c}10.539 * * * \\
(3.524)\end{array}$ & $\begin{array}{c}5.509 \\
(2.399)\end{array}$ & $\begin{array}{c}8.467 * * * \\
(3.439)\end{array}$ \\
\hline Percent High School & $\begin{array}{l}16.163 \\
(3.284)\end{array}$ & $\begin{array}{l}15.489 \\
(3.274)\end{array}$ & $\begin{array}{c}17.019 * * * \\
(3.096)\end{array}$ & $\begin{array}{l}14.296 \\
(3.094)\end{array}$ & $\begin{array}{c}16.744 * * * \\
(3.123)\end{array}$ \\
\hline Percent College & $\begin{array}{c}6.676 \\
(2.570)\end{array}$ & $\begin{array}{c}5.654 \\
(1.987)\end{array}$ & $\begin{array}{c}7.975 * * * \\
(2.643)\end{array}$ & $\begin{array}{c}5.194 \\
(2.121)\end{array}$ & $\begin{array}{c}7.137 * * * \\
(2.525)\end{array}$ \\
\hline Students Per-Teacher & $\begin{array}{l}16.913 \\
(4.379)\end{array}$ & $\begin{array}{l}17.485 \\
(4.929)\end{array}$ & $\begin{array}{c}15.914 * * * \\
(2.949)\end{array}$ & $\begin{array}{l}19.732 \\
(6.099)\end{array}$ & $\begin{array}{c}16.031 * * * \\
(3.212)\end{array}$ \\
\hline Unemployment Rate & $\begin{array}{l}10.263 \\
(3.762)\end{array}$ & $\begin{array}{l}10.315 \\
(4.232)\end{array}$ & $\begin{array}{l}10.196 \\
(3.067)\end{array}$ & $\begin{array}{l}10.540 \\
(4.383)\end{array}$ & $\begin{array}{l}10.177 \\
(3.547)\end{array}$ \\
\hline Province Has Family Physician Program & $\begin{array}{l}0.281 \\
(0.450)\end{array}$ & $\begin{array}{c}0.134 \\
(0.341)\end{array}$ & $\begin{array}{c}0.570 * * * \\
(0.496)\end{array}$ & $\begin{array}{c}0.234 \\
(0.425)\end{array}$ & $\begin{array}{l}0.295^{*} \\
(0.456)\end{array}$ \\
\hline Motor Vehicles Per capita & $\begin{array}{l}161.443 \\
(78.350)\end{array}$ & $\begin{array}{l}134.716 \\
(79.156)\end{array}$ & $\begin{array}{c}195.424 * * * \\
(62.680)\end{array}$ & $\begin{array}{l}104.133 \\
(87.458)\end{array}$ & $\begin{array}{c}179.285^{* * *} \\
(65.876)\end{array}$ \\
\hline Governing Party & $\begin{array}{c}0.609 \\
(0.488)\end{array}$ & $\begin{array}{c}0.538 \\
(0.499)\end{array}$ & $\begin{array}{c}0.749 * * * \\
(0.434)\end{array}$ & $\begin{array}{c}0.455 \\
(0.499)\end{array}$ & $\begin{array}{c}0.657 * * * \\
(0.475)\end{array}$ \\
\hline Population & $\begin{array}{c}884.199 \\
(1460.947)\end{array}$ & $\begin{array}{c}609.654 \\
(540.491)\end{array}$ & $\begin{array}{c}1425.845^{* * * *} \\
(2310.550)\end{array}$ & $\begin{array}{c}366.738 \\
(237.456)\end{array}$ & $\begin{array}{c}1046.100 * * * \\
(1635.670)\end{array}$ \\
\hline Observations & 877 & 582 & 295 & 209 & 668 \\
\hline
\end{tabular}

Notes: Standard deviations are in parentheses. ${ }^{*}, *$, and $* * *$ indicate that mean is statistically different between the sample in columns (2) and (3) or columns (4) and (5) at the 10\%, 5\%, and 1\% levels, respectively. 
Table 2

The Estimates of Time-Varying Province Characteristics on Any Natural Gas

\begin{tabular}{|c|c|c|c|c|c|}
\hline Dependent Variable & (1) & (2) & (3) & (4) & (5) \\
\hline \multirow[t]{2}{*}{ Hospitals Per 100K } & $-0.269 *$ & -0.028 & -0.046 & $-0.105^{*}$ & -0.103 \\
\hline & $(0.142)$ & $(0.071)$ & $(0.058)$ & $(0.062)$ & $(0.067)$ \\
\hline \multirow[t]{2}{*}{ Hospitals Beds Per 100K } & $46.234 * * *$ & 0.444 & -0.524 & -4.537 & -2.566 \\
\hline & $(16.823)$ & $(4.791)$ & $(4.160)$ & $(3.903)$ & $(3.786)$ \\
\hline \multirow[t]{2}{*}{ Physicians Per 100K } & $32.635 * * *$ & $3.710^{*}$ & -1.777 & -0.957 & -1.972 \\
\hline & $(9.753)$ & $(2.062)$ & $(2.618)$ & $(2.691)$ & $(2.834)$ \\
\hline \multirow[t]{2}{*}{ Log Percent High School } & $0.153 * * *$ & $0.031 * * *$ & $0.029 *$ & 0.006 & 0.002 \\
\hline & $(0.037)$ & $(0.011)$ & $(0.016)$ & $(0.015)$ & $(0.013)$ \\
\hline \multirow[t]{2}{*}{ Log Percent College } & $0.293 * * *$ & 0.016 & 0.026 & 0.004 & 0.006 \\
\hline & $(0.064)$ & $(0.024)$ & $(0.026)$ & $(0.028)$ & $(0.026)$ \\
\hline \multirow[t]{2}{*}{ Log Students Per Teacher } & $-0.091 * *$ & 0.010 & 0.010 & -0.003 & 0.008 \\
\hline & $(0.043)$ & $(0.012)$ & $(0.012)$ & $(0.013)$ & $(0.014)$ \\
\hline \multirow[t]{2}{*}{ Unemployment Rate } & -0.743 & $-0.654 *$ & -0.080 & -0.156 & 0.388 \\
\hline & $(0.594)$ & $(0.371)$ & $(0.324)$ & $(0.348)$ & $(0.361)$ \\
\hline \multirow[t]{2}{*}{ Family Physician Program } & 0.023 & 0.013 & -0.044 & -0.021 & -0.024 \\
\hline & $(0.040)$ & $(0.040)$ & $(0.056)$ & $(0.062)$ & $(0.066)$ \\
\hline \multirow[t]{2}{*}{ Log Vehicles PC } & $0.481 * * *$ & 0.006 & -0.004 & -0.000 & -0.001 \\
\hline & $(0.113)$ & $(0.014)$ & $(0.005)$ & $(0.004)$ & $(0.004)$ \\
\hline \multirow[t]{2}{*}{ Governing Party } & $0.164 * *$ & 0.036 & 0.050 & 0.044 & 0.034 \\
\hline & $(0.065)$ & $(0.064)$ & $(0.083)$ & $(0.057)$ & $(0.062)$ \\
\hline \multicolumn{6}{|l|}{ Controls For } \\
\hline Year Fixed Effects & Yes & Yes & Yes & Yes & Yes \\
\hline Province Fixed Effects & No & Yes & Yes & Yes & Yes \\
\hline Province-specific Linear Time Trends & No & No & Yes & Yes & Yes \\
\hline Province-specific Quadratic Time Trends & No & No & No & Yes & Yes \\
\hline Region-by-Year Fixed Effects & No & No & No & No & Yes \\
\hline
\end{tabular}

Notes: Each cell corresponds to a separate regression, where the "dependent variable" is regressed on Any Natural Gas conditional on control variables as indicated above. Robust standard errors, clustered at the province level, are in parentheses. A *, $* *$, or $* * *$ indicates significance at the $95 \%, 99 \%$, or $99.9 \%$ levels, respectively. Sample sizes are 797 for Hospitals Per 100K, Hospitals Beds Per 100K, Students per Teacher, \% with college education, 400 for Physicians Per 100K; 636 for Percent High School, Vehicles per Capita, and Unemployment Rate; and 877 for Family Physician Program, and Governing Party Affiliation. 
Table 3

The Estimates of Time-Varying Province Characteristics on Natural Gas Intensity

\begin{tabular}{|c|c|c|c|c|c|}
\hline Dependent Variable & (1) & (2) & (3) & (4) & (5) \\
\hline Hospitals Per $100 \mathrm{~K}$ & $-0.022 * * *$ & -0.005 & -0.000 & -0.007 & -0.019 \\
\hline \multirow{3}{*}{ Hospitals Beds Per $100 \mathrm{~K}$} & $(0.008)$ & $(0.009)$ & $(0.013)$ & $(0.014)$ & $(0.015)$ \\
\hline & $3.256^{* *}$ & $-1.351 * *$ & $-1.769^{*}$ & 0.887 & 0.746 \\
\hline & $(1.334)$ & $(0.655)$ & $(0.952)$ & $(1.183)$ & $(1.142)$ \\
\hline \multirow[t]{2}{*}{ Physicians Per 100K } & $3.572 * * *$ & $-0.651 * *$ & -0.294 & 0.200 & 0.399 \\
\hline & $(1.341)$ & $(0.291)$ & $(0.539)$ & $(0.547)$ & $(0.488)$ \\
\hline \multirow[t]{2}{*}{ Log Percent High School } & $0.014 * * *$ & 0.001 & $-0.005^{*}$ & -0.001 & -0.000 \\
\hline & $(0.002)$ & $(0.001)$ & $(0.003)$ & $(0.002)$ & $(0.002)$ \\
\hline \multirow[t]{2}{*}{ Log Percent College } & $0.023 * * *$ & 0.001 & -0.002 & 0.001 & 0.003 \\
\hline & $(0.005)$ & $(0.002)$ & $(0.005)$ & $(0.005)$ & $(0.004)$ \\
\hline \multirow[t]{2}{*}{ Log Students Per Teacher } & -0.003 & 0.002 & $0.007 * *$ & -0.001 & -0.001 \\
\hline & $(0.003)$ & $(0.001)$ & $(0.003)$ & $(0.002)$ & $(0.002)$ \\
\hline \multirow[t]{2}{*}{ Unemployment Rate } & 0.013 & $-0.066^{*}$ & 0.088 & -0.009 & -0.021 \\
\hline & $(0.033)$ & $(0.036)$ & $(0.066)$ & $(0.066)$ & $(0.064)$ \\
\hline \multirow[t]{2}{*}{ Family Physician Program } & 0.002 & 0.003 & -0.012 & -0.002 & 0.002 \\
\hline & $(0.003)$ & $(0.003)$ & $(0.010)$ & $(0.014)$ & $(0.012)$ \\
\hline \multirow[t]{2}{*}{ Log Vehicles PC } & $0.022 * * *$ & $-0.003 *$ & 0.000 & 0.001 & 0.002 \\
\hline & $(0.005)$ & $(0.002)$ & $(0.001)$ & $(0.001)$ & $(0.001)$ \\
\hline \multirow[t]{2}{*}{ Governing Party } & 0.005 & -0.005 & -0.013 & 0.003 & 0.008 \\
\hline & $(0.007)$ & $(0.008)$ & $(0.014)$ & $(0.008)$ & $(0.010)$ \\
\hline \multicolumn{6}{|l|}{ Controls For } \\
\hline Year Fixed Effects & Yes & Yes & Yes & Yes & Yes \\
\hline Province Fixed Effects & No & Yes & Yes & Yes & Yes \\
\hline Province-specific Linear Time Trends & No & No & Yes & Yes & Yes \\
\hline Province-specific Quadratic Time Trends & No & No & No & Yes & Yes \\
\hline Region-by-Year Fixed Effects & No & No & No & No & Yes \\
\hline
\end{tabular}

Notes: Each cell corresponds to a separate regression, where the "dependent variable" is regressed on Natural Gas Intensity conditional on control variables as indicated above. Robust standard errors, clustered at the province level, are in parentheses. A*,**, or $* * *$ indicates significance at the $95 \%, 99 \%$, or $99.9 \%$ levels, respectively. Sample sizes are 797 for Hospitals Per 100K, Hospitals Beds Per 100K, Students per Teacher, \% with college education, 400 for Physicians Per 100K; 636 for Percent High School, Vehicles per Capita, and Unemployment Rate; and 877 for Family Physician Program, and Governing Party Affiliation. 
Table 4

The Estimates of Any Natural Gas on Jointly Specified Time-varying Observable Province

Characteristics

\begin{tabular}{|c|c|c|c|c|c|}
\hline Variable & (1) & (2) & (3) & $(4)$ & $(5)$ \\
\hline Hospitals Per-100 K & $\begin{array}{c}-0.079 * * * \\
(0.028)\end{array}$ & $\begin{array}{c}0.014 \\
(0.031)\end{array}$ & $\begin{array}{l}-0.011 \\
(0.023)\end{array}$ & $\begin{array}{l}-0.006 \\
(0.027)\end{array}$ & $\begin{array}{l}-0.019 \\
(0.028)\end{array}$ \\
\hline Hospital Beds Per-100 K & $\begin{array}{c}0.001 \\
(0.000)\end{array}$ & $\begin{array}{l}-0.000 \\
(0.000)\end{array}$ & $\begin{array}{l}-0.000 \\
(0.000)\end{array}$ & $\begin{array}{l}-0.000 \\
(0.000)\end{array}$ & $\begin{array}{l}-0.000 \\
(0.000)\end{array}$ \\
\hline Physicians Per-100 K & $\begin{array}{c}0.001 \\
(0.001)\end{array}$ & $\begin{array}{c}0.000 \\
(0.001)\end{array}$ & $\begin{array}{c}0.001 \\
(0.001)\end{array}$ & $\begin{array}{c}0.001 \\
(0.001)\end{array}$ & $\begin{array}{c}0.000 \\
(0.001)\end{array}$ \\
\hline Log Percent High School & $\begin{array}{c}0.554 * * \\
(0.226)\end{array}$ & $\begin{array}{l}0.382^{*} \\
(0.202)\end{array}$ & $\begin{array}{l}0.345^{*} \\
(0.180)\end{array}$ & $\begin{array}{l}0.332 * \\
(0.192)\end{array}$ & $\begin{array}{c}0.127 \\
(0.278)\end{array}$ \\
\hline Log Percent College & $\begin{array}{l}-0.124 \\
(0.143)\end{array}$ & $\begin{array}{l}-0.192 \\
(0.135)\end{array}$ & $\begin{array}{l}-0.071 \\
(0.097)\end{array}$ & $\begin{array}{l}-0.027 \\
(0.104)\end{array}$ & $\begin{array}{l}-0.056 \\
(0.141)\end{array}$ \\
\hline Log Students Per Teacher & $\begin{array}{c}0.208 \\
(0.144)\end{array}$ & $\begin{array}{c}0.164 \\
(0.112)\end{array}$ & $\begin{array}{c}0.118 \\
(0.095)\end{array}$ & $\begin{array}{c}0.090 \\
(0.123)\end{array}$ & $\begin{array}{c}0.052 \\
(0.141)\end{array}$ \\
\hline Unemployment Rate & $\begin{array}{l}-0.014 * \\
(0.007)\end{array}$ & $\begin{array}{c}-0.014 * * \\
(0.006)\end{array}$ & $\begin{array}{l}-0.006 \\
(0.006)\end{array}$ & $\begin{array}{l}-0.004 \\
(0.005)\end{array}$ & $\begin{array}{c}0.006 \\
(0.010)\end{array}$ \\
\hline Family Doctor & $\begin{array}{l}-0.062 \\
(0.074)\end{array}$ & $\begin{array}{l}-0.008 \\
(0.063)\end{array}$ & $\begin{array}{l}-0.049 \\
(0.054)\end{array}$ & $\begin{array}{l}-0.030 \\
(0.051)\end{array}$ & $\begin{array}{l}-0.029 \\
(0.058)\end{array}$ \\
\hline Log MV Per 1000 People & $\begin{array}{c}0.209 * * * \\
(0.064)\end{array}$ & $\begin{array}{c}0.205 * * * \\
(0.061)\end{array}$ & $\begin{array}{c}-0.054 \\
(0.060)\end{array}$ & $\begin{array}{l}-0.069 \\
(0.049)\end{array}$ & $\begin{array}{l}-0.026 \\
(0.074)\end{array}$ \\
\hline Governing Party & $\begin{array}{c}0.094^{* *} \\
(0.042)\end{array}$ & $\begin{array}{c}0.012 \\
(0.042)\end{array}$ & $\begin{array}{c}0.029 \\
(0.040)\end{array}$ & $\begin{array}{c}0.034 \\
(0.039)\end{array}$ & $\begin{array}{c}0.023 \\
(0.039)\end{array}$ \\
\hline $\begin{array}{l}\text { F-test of Joint Significance } \\
P \text {-value }\end{array}$ & $\begin{array}{l}8.07 \\
0.00\end{array}$ & $\begin{array}{l}3.10 \\
0.00\end{array}$ & $\begin{array}{l}1.19 \\
0.30\end{array}$ & $\begin{array}{l}1.06 \\
0.40\end{array}$ & $\begin{array}{l}0.22 \\
0.99\end{array}$ \\
\hline Observations & 877 & 877 & 877 & 877 & 877 \\
\hline Controls For & & & & & \\
\hline Year Fixed Effects & Yes & Yes & Yes & Yes & Yes \\
\hline Province Fixed Effects & No & Yes & Yes & Yes & Yes \\
\hline Province-specific Linear Time Trends & No & No & Yes & Yes & Yes \\
\hline Province-specific Quadratic Time Trends & No & No & No & Yes & Yes \\
\hline Region-by-Year Fixed Effects & No & No & No & No & Yes \\
\hline
\end{tabular}


Table 5

The Estimates of Natural Gas Intensity on Jointly Specified Time-varying Observable Province

\begin{tabular}{|c|c|c|c|c|c|}
\hline \multicolumn{6}{|c|}{ Characteristics } \\
\hline Variable & $(1)$ & $(2)$ & (3) & $(4)$ & $(5)$ \\
\hline \multirow[t]{2}{*}{ Hospitals Per-100 K } & -0.758 & 0.589 & -0.006 & -0.169 & -0.269 \\
\hline & $(0.501)$ & $(0.387)$ & $(0.180)$ & $(0.208)$ & $(0.256)$ \\
\hline \multirow[t]{2}{*}{ Hospital Beds Per-100 K } & 0.003 & $-0.022 * * *$ & $-0.007^{*}$ & -0.003 & -0.003 \\
\hline & $(0.007)$ & $(0.006)$ & $(0.004)$ & $(0.004)$ & $(0.005)$ \\
\hline \multirow[t]{2}{*}{ Physicians Per-100 K } & $0.033 * * *$ & $0.013 * *$ & 0.002 & 0.000 & 0.000 \\
\hline & $(0.012)$ & $(0.005)$ & $(0.004)$ & $(0.002)$ & $(0.003)$ \\
\hline \multirow[t]{2}{*}{ Log Percent High School } & $7.922 *$ & $5.629 * * *$ & $-2.842 * *$ & -1.060 & -0.986 \\
\hline & $(4.475)$ & $(2.121)$ & $(1.329)$ & $(0.734)$ & $(1.682)$ \\
\hline \multirow[t]{2}{*}{ Log Percent College } & 2.673 & 0.041 & $1.625^{* *}$ & 0.632 & 0.893 \\
\hline & $(3.660)$ & $(1.206)$ & $(0.705)$ & $(0.538)$ & $(0.683)$ \\
\hline \multirow[t]{2}{*}{ Log Students Per Teacher } & 4.344 & $2.493 * *$ & $2.068 * * *$ & -0.789 & -0.580 \\
\hline & $(3.340)$ & $(1.096)$ & $(0.766)$ & $(0.525)$ & $(0.572)$ \\
\hline \multirow[t]{2}{*}{ Unemployment Rate } & -0.059 & -0.070 & 0.006 & 0.027 & 0.028 \\
\hline & $(0.108)$ & $(0.046)$ & $(0.036)$ & $(0.022)$ & $(0.035)$ \\
\hline \multirow[t]{2}{*}{ Family Doctor } & -0.979 & 0.023 & -0.429 & -0.015 & 0.115 \\
\hline & $(1.277)$ & $(0.492)$ & $(0.382)$ & $(0.284)$ & $(0.293)$ \\
\hline \multirow[t]{2}{*}{ Log MV Per 1000 People } & 0.446 & 0.323 & $-1.093 * *$ & -0.025 & 0.208 \\
\hline & $(1.034)$ & $(0.453)$ & $(0.443)$ & $(0.276)$ & $(0.439)$ \\
\hline \multirow[t]{2}{*}{ Governing Party } & 0.695 & -0.198 & -0.282 & 0.066 & 0.146 \\
\hline & $(1.061)$ & $(0.474)$ & $(0.288)$ & $(0.146)$ & $(0.189)$ \\
\hline F-test of Joint Significance & 3.62 & 4.87 & 4.06 & 1.21 & 1.02 \\
\hline$P$-value & 0.00 & 0.00 & 0.00 & 0.30 & 0.43 \\
\hline Observations & 877 & 877 & 877 & 877 & 877 \\
\hline \multicolumn{6}{|l|}{ Controls For } \\
\hline Year Fixed Effects & Yes & Yes & Yes & Yes & Yes \\
\hline Province Fixed Effects & No & Yes & Yes & Yes & Yes \\
\hline Province-specific Linear Trends & No & No & Yes & Yes & Yes \\
\hline Province-specific Quadratic Trends & No & No & No & Yes & Yes \\
\hline Region-by-Year Fixed Effects & No & No & No & No & Yes \\
\hline
\end{tabular}

Notes: Robust standard errors, clustered at the province level, are in parentheses. $\mathrm{A}{ }^{*},{ }^{* *}$, or $* * *$ indicates significance at the $95 \%, 99 \%$, or $99.9 \%$ levels, respectively. 
Table 6

The Impact of Any Natural Gas on the Logarithm of Infant Mortality Rate

\begin{tabular}{|c|c|c|c|c|c|c|c|}
\hline Variable & $(1)$ & $(2)$ & (3) & $(4)$ & $(5)$ & $(6)$ & $(7)$ \\
\hline Any Natural Gas & $\begin{array}{c}0.490 * * * \\
(0.105)\end{array}$ & $\begin{array}{c}0.576 * * * \\
(0.124)\end{array}$ & $\begin{array}{c}-0.271 * * \\
(0.113)\end{array}$ & $\begin{array}{l}-0.025 \\
(0.103)\end{array}$ & $\begin{array}{l}-0.032 \\
(0.113)\end{array}$ & $\begin{array}{l}-0.036 \\
(0.115)\end{array}$ & $\begin{array}{l}-0.127 \\
(0.116)\end{array}$ \\
\hline Hospitals Per-100 K & & & & & & $\begin{array}{c}0.000 \\
(0.051)\end{array}$ & $\begin{array}{c}-0.004 \\
(0.060)\end{array}$ \\
\hline Hospital Beds Per-100 K & & & & & & $\begin{array}{l}-0.000 \\
(0.001)\end{array}$ & $\begin{array}{c}0.000 \\
(0.001)\end{array}$ \\
\hline Physicians Per-100 K & & & & & & $\begin{array}{c}0.000 \\
(0.001)\end{array}$ & $\begin{array}{c}0.000 \\
(0.001)\end{array}$ \\
\hline Log Per Capita Sub-regional GDP & & & & & & $\begin{array}{c}0.328 \\
(0.235)\end{array}$ & $\begin{array}{c}0.120 \\
(0.485)\end{array}$ \\
\hline Log Percent High School & & & & & & $\begin{array}{c}0.225 \\
(0.223)\end{array}$ & $\begin{array}{l}-0.069 \\
(0.257)\end{array}$ \\
\hline Log Percent College & & & & & & $\begin{array}{l}-0.318 \\
(0.387)\end{array}$ & $\begin{array}{c}0.121 \\
(0.479)\end{array}$ \\
\hline Log Students Per Teacher & & & & & & $\begin{array}{l}-0.039 \\
(0.345)\end{array}$ & $\begin{array}{c}0.063 \\
(0.371)\end{array}$ \\
\hline Unemployment Rate & & & & & & $\begin{array}{c}0.002 \\
(0.015)\end{array}$ & $\begin{array}{c}0.014 \\
(0.018)\end{array}$ \\
\hline Family Doctor & & & & & & $\begin{array}{c}0.008 \\
(0.075)\end{array}$ & $\begin{array}{l}-0.027 \\
(0.070)\end{array}$ \\
\hline Log MV Per 1000 People & & & & & & $\begin{array}{l}-0.191 \\
(0.166)\end{array}$ & $\begin{array}{c}0.207 \\
(0.190)\end{array}$ \\
\hline Governing Party & & & & & & $\begin{array}{l}-0.023 \\
(0.065)\end{array}$ & $\begin{array}{l}-0.010 \\
(0.067)\end{array}$ \\
\hline Observations & 877 & 877 & 877 & 877 & 877 & 877 & 877 \\
\hline Controls For & & & & & & & \\
\hline Year Fixed Effects & No & Yes & Yes & Yes & Yes & Yes & Yes \\
\hline Province Fixed Effects & No & No & Yes & Yes & Yes & Yes & Yes \\
\hline Province-specific Linear Trends & No & No & No & Yes & Yes & Yes & Yes \\
\hline Province-specific Quadratic Trends & No & No & No & No & Yes & Yes & Yes \\
\hline Time-varying Province Characteristics & No & No & No & No & No & Yes & Yes \\
\hline Region-by-year Fixed Effects & No & No & No & No & No & No & Yes \\
\hline
\end{tabular}

Notes: Robust standard errors, clustered at the province level, are in parentheses. A *,**, or *** indicates significance at the $90 \%, 95 \%$, or $99 \%$ levels, respectively. 
Table 7

The Impact of Natural Gas Intensity on the Logarithm of Infant Mortality Rate

\begin{tabular}{|c|c|c|c|c|c|c|c|}
\hline Variable & $(1)$ & $(2)$ & $(3)$ & $(4)$ & (5) & $(6)$ & $(7)$ \\
\hline Natural Gas Intensity & $\begin{array}{c}0.033 * * * \\
(0.007)\end{array}$ & $\begin{array}{c}0.031 * * * \\
(0.007)\end{array}$ & $\begin{array}{c}-0.046 * * * \\
(0.009)\end{array}$ & $\begin{array}{c}-0.042 * * * \\
(0.015)\end{array}$ & $\begin{array}{c}-0.041 * * \\
(0.017)\end{array}$ & $\begin{array}{c}-0.042 * * \\
(0.017)\end{array}$ & $\begin{array}{l}-0.040^{*} \\
(0.021)\end{array}$ \\
\hline Hospitals Per-100 K & & & & & & $\begin{array}{l}-0.006 \\
(0.052)\end{array}$ & $\begin{array}{c}-0.013 \\
(0.061)\end{array}$ \\
\hline Hospital Beds Per-100 K & & & & & & $\begin{array}{l}-0.000 \\
(0.001)\end{array}$ & $\begin{array}{c}0.000 \\
(0.001)\end{array}$ \\
\hline Physicians Per-100 K & & & & & & $\begin{array}{c}0.000 \\
(0.001)\end{array}$ & $\begin{array}{c}0.000 \\
(0.001)\end{array}$ \\
\hline Log Per Capita Sub-Regional GDP & & & & & & $\begin{array}{c}0.299 \\
(0.232)\end{array}$ & $\begin{array}{c}0.170 \\
(0.464)\end{array}$ \\
\hline Log Percent High School & & & & & & $\begin{array}{c}0.256 \\
(0.224)\end{array}$ & $\begin{array}{l}-0.031 \\
(0.258)\end{array}$ \\
\hline Log Percent College & & & & & & $\begin{array}{l}-0.365 \\
(0.391)\end{array}$ & $\begin{array}{c}0.059 \\
(0.477)\end{array}$ \\
\hline Log Students Per Teacher & & & & & & $\begin{array}{l}-0.075 \\
(0.345)\end{array}$ & $\begin{array}{c}0.026 \\
(0.371)\end{array}$ \\
\hline Unemployment Rate & & & & & & $\begin{array}{c}0.003 \\
(0.015)\end{array}$ & $\begin{array}{c}0.014 \\
(0.018)\end{array}$ \\
\hline Family Doctor & & & & & & $\begin{array}{c}0.008 \\
(0.074)\end{array}$ & $\begin{array}{l}-0.019 \\
(0.070)\end{array}$ \\
\hline Log MV Per 1000 People & & & & & & $\begin{array}{l}-0.180 \\
(0.166)\end{array}$ & $\begin{array}{c}0.214 \\
(0.190)\end{array}$ \\
\hline Governing Party & & & & & & $\begin{array}{l}-0.022 \\
(0.066)\end{array}$ & $\begin{array}{l}-0.005 \\
(0.069)\end{array}$ \\
\hline Observations & 877 & 877 & 877 & 877 & 877 & 877 & 877 \\
\hline Controls For & & & & & & & \\
\hline Year Fixed Effects & No & Yes & Yes & Yes & Yes & Yes & Yes \\
\hline Province Fixed Effects & No & No & Yes & Yes & Yes & Yes & Yes \\
\hline Province-specific Linear Trends & No & No & No & Yes & Yes & Yes & Yes \\
\hline Province-specific Quadratic Trends & No & No & No & No & Yes & Yes & Yes \\
\hline Time-varying Province Characteristics & No & No & No & No & No & Yes & Yes \\
\hline Region-by-year Fixed Effects & No & No & No & No & No & No & Yes \\
\hline
\end{tabular}

Notes: Robust standard errors, clustered at the province level, are in parentheses. A *, ${ }^{* *}$, or *** indicates significance at the $90 \%, 95 \%$, or $99 \%$ levels, respectively. 
Table 8

The Impact of Natural Gas Intensity on Infant Deaths and Births

(1) (2) (3) (4) (5)

Panel A
Dependent Variable: Log Infant Deaths

\begin{tabular}{|c|c|c|c|c|c|c|c|}
\hline Natural Gas Intensity & $\begin{array}{c}0.032 * * * \\
(0.009)\end{array}$ & $\begin{array}{c}0.002 \\
(0.009)\end{array}$ & $\begin{array}{c}-0.049 * * * \\
(0.012)\end{array}$ & $\begin{array}{c}-0.044^{* *} \\
(0.018)\end{array}$ & $\begin{array}{c}-0.050^{* * * *} \\
(0.016)\end{array}$ & $\begin{array}{c}-0.051 * * * \\
(0.017)\end{array}$ & $\begin{array}{c}-0.051 * * * \\
(0.019)\end{array}$ \\
\hline Log Births & $\begin{array}{c}1.294 * * * \\
(0.055)\end{array}$ & $\begin{array}{l}1.368 * * * \\
(0.050)\end{array}$ & $\begin{array}{l}-0.108 \\
(0.353)\end{array}$ & $\begin{array}{c}1.693 * * \\
(0.705)\end{array}$ & $\begin{array}{l}1.353 * \\
(0.753)\end{array}$ & $\begin{array}{l}1.106 \\
(0.762)\end{array}$ & $\begin{array}{l}1.015 \\
(0.843)\end{array}$ \\
\hline \multicolumn{8}{|l|}{$\begin{array}{l}\text { Panel B } \\
\text { Dependent Variable: Log Infant Births }\end{array}$} \\
\hline Natural Gas Intensity & $\begin{array}{l}0.045^{* *} \\
(0.019) \\
\end{array}$ & $\begin{array}{c}0.057 * * * \\
(0.021)\end{array}$ & $\begin{array}{c}0.006^{* *} \\
(0.003)\end{array}$ & $\begin{array}{c}0.000 \\
(0.001)\end{array}$ & $\begin{array}{c}0.001 \\
(0.001) \\
\end{array}$ & $\begin{array}{c}0.001 \\
(0.001) \\
\end{array}$ & $\begin{array}{c}0.001 \\
(0.001) \\
\end{array}$ \\
\hline Observations & 877 & 877 & 877 & 877 & 877 & 877 & 877 \\
\hline \multicolumn{8}{|l|}{ Controls For } \\
\hline Year Fixed Effects & No & Yes & Yes & Yes & Yes & Yes & Yes \\
\hline Province Fixed Effects & No & No & Yes & Yes & Yes & Yes & Yes \\
\hline Province-specific Linear Trends & No & No & No & Yes & Yes & Yes & Yes \\
\hline Province-specific Quadratic Trends & No & No & No & No & Yes & Yes & Yes \\
\hline Time-varying Province Characteristics & No & No & No & No & No & Yes & Yes \\
\hline Region-by-year Fixed Effects & No & No & No & No & No & No & Yes \\
\hline
\end{tabular}

Notes: Robust standard errors, clustered at the province level, are in parentheses. A *, ${ }^{* *}$, or *** indicates significance at the $95 \%, 99 \%$, or $99.9 \%$ levels, respectively. 
Table 9

The Impact of Natural Gas Intensity on the Logarithm of Infant Mortality Rate, Robustness Analyses with Alternative Subsamples

\begin{tabular}{|c|c|c|c|c|c|c|c|}
\hline Variable & $(1)$ & $(2)$ & (3) & $(4)$ & $(5)$ & $(6)$ & $(7)$ \\
\hline \multicolumn{8}{|l|}{ Panel A: Natural Gas Sample } \\
\hline Natural Gas Intensity & $\begin{array}{l}0.020^{* *} \\
(0.008)\end{array}$ & $\begin{array}{c}0.026^{* * * *} \\
(0.008)\end{array}$ & $\begin{array}{l}-0.017^{*} \\
(0.010)\end{array}$ & $\begin{array}{l}-0.018 \\
(0.016)\end{array}$ & $\begin{array}{c}-0.041^{* *} \\
(0.017)\end{array}$ & $\begin{array}{c}-0.040^{* *} \\
(0.018)\end{array}$ & $\begin{array}{l}-0.041^{*} \\
(0.022)\end{array}$ \\
\hline Observations & 668 & 668 & 668 & 668 & 668 & 668 & 668 \\
\hline \multicolumn{8}{|l|}{ Panel B: Istanbul Excluded } \\
\hline Natural Gas Intensity & $\begin{array}{c}0.032 * * * \\
(0.008)\end{array}$ & $\begin{array}{c}0.030^{* * * *} \\
(0.009)\end{array}$ & $\begin{array}{c}-0.045^{* * * *} \\
(0.009)\end{array}$ & $\begin{array}{c}-0.043 * * * \\
(0.015)\end{array}$ & $\begin{array}{c}-0.041 * * \\
(0.017)\end{array}$ & $\begin{array}{c}-0.042^{* *} \\
(0.018)\end{array}$ & $\begin{array}{c}-0.041^{*} \\
(0.021)\end{array}$ \\
\hline Observations & 866 & 866 & 866 & 866 & 866 & 866 & 866 \\
\hline \multicolumn{8}{|c|}{ Panel C: Ankara, Bursa, Eskisehir, Istanbul, and Kocaeli Excluded } \\
\hline Natural Gas Intensity & $\begin{array}{c}0.019 \\
(0.014)\end{array}$ & $\begin{array}{c}0.001 \\
(0.017)\end{array}$ & $\begin{array}{c}-0.045^{* * *} \\
(0.010)\end{array}$ & $\begin{array}{c}-0.046^{* * *} \\
(0.016)\end{array}$ & $\begin{array}{c}-0.043 * * \\
(0.018)\end{array}$ & $\begin{array}{c}-0.045^{* *} \\
(0.019)\end{array}$ & $\begin{array}{l}-0.045^{*} \\
(0.024)\end{array}$ \\
\hline Observations & 822 & 822 & 822 & 822 & 822 & 822 & 822 \\
\hline \multicolumn{8}{|l|}{ Controls For } \\
\hline Year Fixed Effects & No & Yes & Yes & Yes & Yes & Yes & Yes \\
\hline Province Fixed Effects & No & No & Yes & Yes & Yes & Yes & Yes \\
\hline Province-specific Linear Trends & No & No & No & Yes & Yes & Yes & Yes \\
\hline Province-specific Quadratic Trends & No & No & No & No & Yes & Yes & Yes \\
\hline Time-varying Province Characteristics & No & No & No & No & No & Yes & Yes \\
\hline Region-by-year Fixed Effects & No & No & No & No & No & No & Yes \\
\hline
\end{tabular}

Notes: Robust standard errors, clustered at the province level, are in parentheses. A *,**, or ${ }^{* * *}$ indicates significance at the $90 \%, 95 \%$, or $99 \%$ levels, respectively. 
Table A1

Natural Gas Adoption Year and Natural Gas Intensity in 2011 for Provinces with Natural Gas Infrastructure

\begin{tabular}{|c|c|c|c|c|c|}
\hline Province & $\begin{array}{l}\text { Adoption } \\
\text { Year }\end{array}$ & $\begin{array}{l}\text { Natural Gas } \\
\text { Intensity in } 2011\end{array}$ & Province & $\begin{array}{l}\text { Adoption } \\
\text { Year }\end{array}$ & $\begin{array}{l}\text { Natural Gas } \\
\text { Intensity in } 2011\end{array}$ \\
\hline Adana & 2010 & 0.540 & Karaman & 2009 & 9.724 \\
\hline Adiyaman & 2010 & 3.851 & Kars & 2009 & 1.153 \\
\hline Afyonkarahisar & 2008 & 4.316 & Kastamonu & 2009 & 3.783 \\
\hline Aksaray & 2006 & 11.067 & Kayseri & 2005 & 23.603 \\
\hline Amasya & 2008 & 13.272 & Kirikkale & 2007 & 16.491 \\
\hline Ankara & 1988 & 33.943 & Kirklareli & 2009 & 4.160 \\
\hline Antalya & 2009 & 0.046 & Kirsehir & 2007 & 16.865 \\
\hline Balikesir & 2005 & 17.334 & Kocaeli/Izmit & 1996 & 20.319 \\
\hline Bayburt & 2009 & 10.918 & Konya & 2005 & 12.478 \\
\hline Bilecik & 2007 & 26.038 & Kutahya & 2005 & 16.309 \\
\hline Bolu & 2010 & 8.229 & Malatya & 2007 & 19.067 \\
\hline Burdur & 2009 & 3.686 & Manisa & 2007 & 6.914 \\
\hline Bursa & 1992 & 31.613 & Mersin & 2010 & 0.512 \\
\hline Canakkale & 2007 & 12.565 & Nevsehir & 2009 & 6.696 \\
\hline Cankiri & 2009 & 8.726 & Nigde & 2007 & 8.180 \\
\hline Corum & 2005 & 14.606 & Ordu & 2009 & 2.515 \\
\hline Denizli & 2007 & 12.404 & Osmaniye & 2011 & 0.473 \\
\hline Diyarbakir & 2009 & 4.633 & Rize & 2009 & 10.310 \\
\hline Duzce & 2006 & 16.089 & Sakarya & 2005 & 14.684 \\
\hline Edirne & 2009 & 4.965 & Samsun & 2006 & 8.942 \\
\hline Elazig & 2009 & 12.283 & Sanliurfa & 2008 & 3.069 \\
\hline Erzincan & 2009 & 7.396 & Sivas & 2006 & 21.868 \\
\hline Erzurum & 2005 & 8.884 & Tekirdag & 2005 & 10.523 \\
\hline Eskisehir & 1996 & 38.569 & Tokat & 2009 & 3.631 \\
\hline Gaziantep & 2008 & 2.262 & Trabzon & 2010 & 0.672 \\
\hline Hatay & 2010 & 0.103 & Usak & 2006 & 9.910 \\
\hline Isparta & 2009 & 5.141 & Van & 2008 & 1.838 \\
\hline Istanbul & 1992 & 34.446 & Yalova & 2006 & 19.130 \\
\hline Izmir & 2007 & 5.390 & Yozgat & 2007 & 8.685 \\
\hline Kahramanmaras & 2007 & 4.097 & Zonguldak & 2006 & 9.346 \\
\hline Karabuk & 2009 & 9.944 & & & \\
\hline
\end{tabular}

Notes: Provinces without natural gas infrastructure in 2011 are Sirnak, Mus, Hakkari, Aydin, Ardahan, Mugla, Tunceli, Siirt, Batman, Gumushane, Sinop, Mardin, Kilis, Igdir, Artvin, Bingol, Giresun, Bartin, Bitlis, and Agri. In Ankara, Bursa, Eskisehir, Istanbul, and Kocaeli natural gas infrastructure was developed prior to 2001. Natural gas intensity is expressed in per hundred populations. 
Table A2

Infant Mortality Rate by Source

\begin{tabular}{cccc}
\hline Year & $\begin{array}{c}\text { World Health } \\
\text { Organisation }\end{array}$ & $\begin{array}{c}\text { United } \\
\text { Nations }\end{array}$ & $\begin{array}{c}\text { Turkish } \\
\text { Statistical } \\
\text { Institute }\end{array}$ \\
\hline 2001 & 26.1 & 31 & 11.8 \\
2002 & 24.2 & 29 & 11.1 \\
2003 & 22.3 & 26 & 10.9 \\
2004 & 20.5 & 24 & 9.4 \\
2005 & 18.9 & 22 & 8.9 \\
2006 & 17.4 & 20 & 8.8 \\
2007 & 15.9 & 18 & 8.7 \\
2008 & 14.7 & 16 & 8.5 \\
2009 & 13.6 & 15 & 7.9 \\
2010 & 12.5 & 14 & 7.7 \\
2011 & 11.5 & --- & 7.6 \\
\hline
\end{tabular}

Sources: Turkish Statistical Institute;

World Health Organisation: Child Mortality Estimates;

United Nations: The State of the World's Children.

Note: We do not have data on the infant mortality rate for 2011 from the United Nations. 
Table A3

The Impact of Natural Gas Intensity on Log Particulate Matter

\begin{tabular}{|c|c|}
\hline Natural Gas Intensity & $\begin{array}{c}-0.040 * * * \\
(0.013)\end{array}$ \\
\hline Hospitals Per-100 K & $\begin{array}{l}-0.020 \\
(0.101)\end{array}$ \\
\hline Hospital Beds Per-100 K & $\begin{array}{c}0.001 \\
(0.001)\end{array}$ \\
\hline Physicians Per-100 K & $\begin{array}{l}-0.001 \\
(0.001)\end{array}$ \\
\hline Log Per Capita Sub-regional GDP & $\begin{array}{l}-0.316 \\
(0.254)\end{array}$ \\
\hline Log Percent High School & $\begin{array}{c}0.213 \\
(0.251)\end{array}$ \\
\hline Log Percent College & $\begin{array}{l}-0.251 \\
(0.373)\end{array}$ \\
\hline Log Students Per Teacher & $\begin{array}{c}0.522 \\
(0.496)\end{array}$ \\
\hline Unemployment Rate & $\begin{array}{c}0.001 \\
(0.019)\end{array}$ \\
\hline Family Doctor & $\begin{array}{c}0.059 \\
(0.064)\end{array}$ \\
\hline Log MV Per 1000 People & $\begin{array}{c}0.119 \\
(0.164)\end{array}$ \\
\hline Governing Party & $\begin{array}{c}0.023 \\
(0.046)\end{array}$ \\
\hline $\begin{array}{l}\text { First Stage F-test } \\
P \text {-value }\end{array}$ & $\begin{array}{c}10.27 \\
0.00\end{array}$ \\
\hline Observations & 490 \\
\hline
\end{tabular}


Table A4

The Impact of Any Natural Gas on the Logarithm of Infant Mortality Rate, Population and Birth Density Weighted Regressions

\begin{tabular}{lc}
\hline & $(1)$ \\
\hline Panel A: Mean Population Density Weighted Regressions & $-0.032^{* *}$ \\
\hline Natural Gas Intensity & $(0.016)$ \\
\hline Panel B: Mean Birth Density Weighted Regressions & $-0.031^{*}$ \\
\hline Natural Gas Intensity & $(0.016)$ \\
\hline & \\
\hline & 877 \\
\hline$\quad$ Conservations & \\
Year Fixed Forfects & Yes \\
Province Fixed Effects & Yes \\
Region-by-year Fixed Effects & Yes \\
Province-specific Linear Trends & Yes \\
Province-specific Quadratic Trends & Yes \\
Time-varying Province Characteristics & Yes \\
\hline Notes: Robust standard errors, clustered at the province level, are in parentheses. A * ${ }^{* *}$, or $* * *$ indicates \\
significance at the $90 \%, 95 \%$, or $99 \%$ levels, respectively.
\end{tabular}

